\title{
Atmospheric aerosol compositions in China: spatial/temporal variability, chemical signature, regional haze distribution and comparisons with global aerosols
}

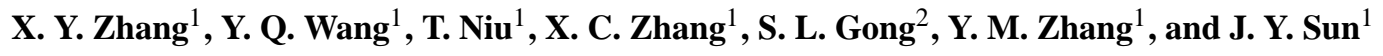 \\ ${ }^{1}$ Key Laboratory for Atmospheric Chemistry, Chinese Academy of Meteorological Sciences, CMA, 46 Zhong Guan Cun S. \\ Ave., Beijing 100081, China \\ ${ }^{2}$ Air Quality Research Division, Science and Technology Branch, Environment Canada, 4905 Dufferin Street, Toronto, \\ Ontario M3H 5T4, Canada
}

Correspondence to: X. Y. Zhang (xiaoye@cams.cma.gov.cn)

Received: 7 May 2011 - Published in Atmos. Chem. Phys. Discuss.: 26 September 2011

Revised: 14 December 2011 - Accepted: 4 January 2012 - Published: 17 January 2012

\begin{abstract}
From 2006 to 2007, the daily concentrations of major inorganic water-soluble constituents, mineral aerosol, organic carbon (OC) and elemental carbon (EC) in ambient $\mathrm{PM}_{10}$ samples were investigated from 16 urban, rural and remote sites in various regions of China, and were compared with global aerosol measurements. A large difference between urban and rural chemical species was found, normally with 1.5 to 2.5 factors higher in urban than in rural sites. Optically-scattering aerosols, such as sulfate $(\sim 16 \%)$, OC $(\sim 15 \%)$, nitrate $(\sim 7 \%)$, ammonium $(\sim 5 \%)$ and mineral aerosol $(\sim 35 \%)$ in most circumstance, are majorities of the total aerosols, indicating a dominant scattering feature of aerosols in China. Of the total OC, $\sim 55 \%-60 \%$ can be attributed to the formation of the secondary organic carbon (SOC). The absorbing aerosol EC only accounts for $\sim 3.5 \%$ of the total $\mathrm{PM}_{10}$. Seasonally, maximum concentrations of most aerosol species were found in winter while mineral aerosol peaks in spring. In addition to the regular seasonal maximum, secondary peaks were found for sulfate and ammonium in summer and for OC and EC in May and June. This can be considered as a typical seasonal pattern in various aerosol components in China. Aerosol acidity was normally neutral in most of urban areas, but becomes some acidic in rural areas. Based on the surface visibility observations from 681 meteorological stations in China between 1957 and 2005, four major haze areas are identified with similar visibility changes, namely, (1) Hua Bei Plain in N. China, and the Guanzhong Plain; (2) E. China with the main body in the Yangtze River Delta area; (3) S. China with most areas of Guangdong and the Pearl River Delta area; (4) The Si Chuan Basin in S. W. China. The degradation of visibility in
\end{abstract}

these areas is linked with the emission changes and high PM concentrations. Such quantitative chemical characterization of aerosols is essential in assessing their role in atmospheric chemistry and weather-climate effects, and in validating atmospheric models.

\section{Introduction}

Tropospheric aerosols are highly variable in time and space from US (Malm and Schichtel, 2004; Tanner et al., 2004), Europe (Querol et al., 2004, 2008; Yin and Harrison, 2008), S. E. Asia (Oanha et al., 2006; Kim et al., 2007), S. Asia (Rastogi and Sarin, 2005; Kumar et al., 2007; Stone et al., 2010) to China (Zhang et al., 1993; He et al., 2001; Hu et al., 2002; Zhang et al., 2002; Yao et al., 2002; Ye et al., 2003; Zhang et al., 2008a), and contain optically-scattering sulfate, organic carbon $(\mathrm{OC})$, nitrate, ammonium product, and mineral aerosol in most circumstance, as well as optically-absorbing materials, mainly elemental carbon (EC) with partial contributions from mineral aerosol (Zhang et al., 2008b; Yang et al., 2009). High loadings of these aerosols induce a forcing for climate change (Forster et al., 2007; Myhre, 2009) in addition to having an adverse effects on weather (Pérez et al., 2006; Wang et al., 2010) and air quality for human health (Delfino et al., 2003; Feng et al., 2007). The uncertainties of the impacts are recognized to be very large, especially when very limited understanding of the regional and global distributions of individual aerosol species is available. This is also further complicated by their mixing status and the influence of aerosols on cloud physics when CCN (cloud condensation 


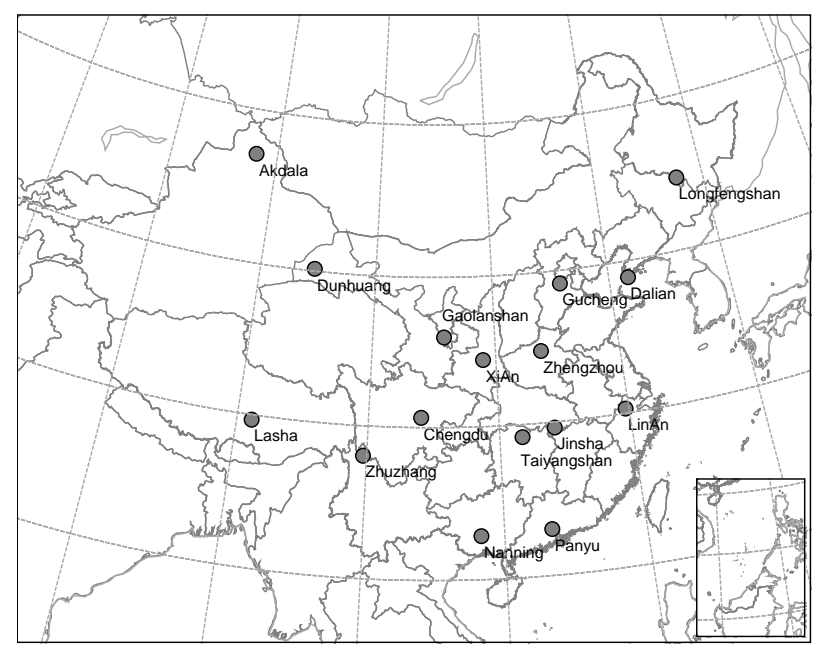

Fig. 1. Locations of sixteen CAWNET stations.

nucleus) activation capacity of mineral aerosol is enhanced through heterogeneous chemical reaction with polluted gases (Kumar et al., 2010; Koehler et al., 2009; Levin et al., 1996), and water-soluble organic aerosol involves into the $\mathrm{CCN}$ activation (Facchini et al., 1999; Decesari et al., 2003; Pöschl et al., 2010).

Various aerosols and their precursors are released by human activities in every part of the world especially in recent decades, but are attracting special attentions in areas of rapid economic growth and high population density, such as in China. Because of China's vast territory, high aerosol loading and complex compositions, many new phenomena and issues have occurred, e.g., the interaction between aerosol and clouds in addition to the traditional cloud physics. Comprehensive understanding of aerosol chemical compositions in China, distributions, variations and signatures is one of the important bases to characterize the aerosols in the world and reduce the uncertainty of their weather-climate effects, and also is a foundation for further understanding the aerosolscloud interaction. Unfortunately, although there were some investigations on various aerosol chemical compositions in China (Zhang et al., 1993; He et al., 2001; Hu et al., 2002; Yao et al., 2002; Ye et al., 2003; Wang et al., 2005; Zhang et al., 2008a, 2009b), the earlier studies were limited in scope and time with very few having data exceeding one year and covering various urban, rural and remote regions of the whole country.

This paper presents a data set on major inorganic watersoluble constituents, mineral aerosol and carbonaceous species (OC and EC) in daily ambient $\mathrm{PM}_{10}$ samples measured from 2006 and 2007 at 16 stations of the CMA Atmosphere Watch Network (CAWNET), covering seasonal variations on a longer basis, which is essential to accurately and objectively assess the impacts of various aerosols in China and their influences at regional and global scales. Visibility changes in recent decades and the exhibiting distributions of major regional haze all over China are also presented. Although there were some investigations on the visibility reduction related with atmospheric haze (Wu et al., 2007) and haze distributions and variations in China, they were limited to some specific regions, such as in Hunan (Liao et al., 2007), the Pearl River Delta region (Deng et al., 2008), Tianjin (Guo, 2008), sixe megacities (Chang et al., 2009), Shenyang (Liu et al., 2010), Nanjing (Yang et al., 2010) and Yichang (Fu et al., 2010).

The purpose of this paper is to assess chemical concentration levels of the urban, regional background, and remote aerosol, and to obtain the seasonal variations at various locations in the haze areas. Through the analysis of aerosol acidities, OC/EC ratios and the SOC component, the chemical signatures are also identified. These observations and analyses provide a general picture of aerosols in China and can also be used in validating model results.

\section{Sample collection and analyses}

\subsection{Site and sampling descriptions}

24-h aerosol filter samples were collected every three days at the 16 CAWNET stations from 2006 to 2007, which are operated by the Chinese Meteorological Administration (CMA), as shown in Fig. 1 and described in details in Table 1. The rural stations are selected in the representative areas with sampling point distantly away from local sources and high above the surrounding ground level. At the urban locations, the sampling points are usually $50-100 \mathrm{~m}$ above the city average elevation in order to receive mixed aerosols rather than those dominated by specific sources. Aerosol samples were collected by using MiniVol ${ }^{\mathrm{TM}}$ air sampler (Airmetrics, Oregon USA), operating at an ambient air flow rate of $51 \mathrm{~min}^{-1}$ for $24 \mathrm{~h}$ from 09:00 a.m. to 09:00 a.m. (Beijing time) the following day. The filtration media were $47 \mathrm{~mm}$ Whatman quartz microfibre filters $(\mathrm{QM} / \mathrm{A})$ that were cleaned by heating at $800^{\circ} \mathrm{C}$ for $3 \mathrm{~h}$ before being used.

\subsection{Aerosol chemical composition analyses}

The elemental concentrations were analyzed directly by an X-Ray Fluorescence (XRF) method using X-Lab 2000 (SPECTRO, Germany) at the Key Laboratory for Atmospheric Chemistry (LAC), Chinese Academy of Meteorological Sciences (CAMS). The XRF spectrometer includes a high-tech detector using a silicon lithium drifted crystal cooled at a low temperature $\left(-90^{\circ} \mathrm{C}\right)$. This crystal is able to discriminate between $\mathrm{X}$-ray photons of different energies, i.e. energy dispersion. Four different targets ( $\mathrm{Mo}, \mathrm{Co}, \mathrm{Al}_{2} \mathrm{O}_{3}$, and Highly Oriented Pyrolytic Graphite (HOPG)) with different energy are employed to identify different elements. For the Mo target, the energy range is $25 \mathrm{keV}$, which is suitable for $\mathrm{Cr}, \mathrm{Mn}, \mathrm{Fe}, \mathrm{Co}, \mathrm{Ni}, \mathrm{Cu}, \mathrm{Zn}, \mathrm{As}, \mathrm{Se}, \mathrm{Br}, \mathrm{Pb}$ and $\mathrm{Zr}$. 
Table 1. CMA Atmosphere Watch Network (CAWNET) site and sampling descriptions.

\begin{tabular}{|c|c|}
\hline Station Name & CAWNET station description \\
\hline $\begin{array}{l}\text { Akdala (AKD) } \\
\left(47^{\circ} 06^{\prime} \mathrm{N}, 87^{\circ} 58^{\prime} \mathrm{E}\right)\end{array}$ & $\begin{array}{l}\text { Remote station, } 562 \mathrm{~m} \text { asl, } 55 \mathrm{~km} \text { west of Fuhai county (Al- } \\
\text { tai area, Xinjiang province, China), and } \sim 250-300 \mathrm{~km} \text { south- } \\
\text { east of Kazakestan. Aerosol samples collected from a } 10 \mathrm{~m} \text {-tall } \\
\text { building. }\end{array}$ \\
\hline $\begin{array}{l}\text { Chengdu (CD) } \\
\left(30^{\circ} 39^{\prime} \mathrm{N}, 104^{\circ} 2.4^{\prime} \mathrm{E}\right)\end{array}$ & $\begin{array}{l}\text { Urban station, } 496 \mathrm{~m} \text { a.s.l., in the center of Chengdu city, } \\
\text { Sichuan province. Aerosol samples collected from a } 91 \mathrm{~m} \text {-tall } \\
\text { building. }\end{array}$ \\
\hline $\begin{array}{l}\text { Dalian (DL) } \\
\left(38^{\circ} 54^{\prime} \mathrm{N}, 121^{\circ} 37.8^{\prime} \mathrm{E}\right)\end{array}$ & $\begin{array}{l}\text { Urban station, } 91.5 \mathrm{~m} \text { a.s.l., southeast of Dalian center at city } \\
\text { margin. Aerosol samples collected from a } 5 \mathrm{~m} \text {-tall building. }\end{array}$ \\
\hline $\begin{array}{l}\text { Dunhuang }(\mathrm{DH}) \\
\left(40^{\circ} 9^{\prime} \mathrm{N}, 94^{\circ} 40.8^{\prime} \mathrm{E}\right)\end{array}$ & $\begin{array}{l}\text { Rural station, } 1139 \mathrm{~m} \text { a.s.l., } 1.5 \mathrm{~km} \text { northeast of Dunhuang city, } \\
\text { Gansu province. Aerosol samples collected from a } 5 \mathrm{~m} \text {-tall } \\
\text { sampling container. }\end{array}$ \\
\hline $\begin{array}{l}\text { Gaolanshan (GLS) } \\
\left(36^{\circ} 0^{\prime} \mathrm{N}, 105^{\circ} 51^{\prime} \mathrm{E}\right)\end{array}$ & $\begin{array}{l}\text { Rural station } 5 \mathrm{~km} \text { north from Lanzhou city ( } 1531 \mathrm{~m} \text { a.s.l.), } \\
\text { Gansu province. Aerosol samples collected from a } 544 \mathrm{~m} \text {-tall } \\
\text { hill. }\end{array}$ \\
\hline $\begin{array}{l}\text { Gucheng (GC) } \\
\left(39^{\circ} 7.8^{\prime} \mathrm{N}, 115^{\circ} 48^{\prime} \mathrm{E}\right)\end{array}$ & $\begin{array}{l}\text { Rural station but within area of rapid urbanization: } 15.2 \mathrm{~m} \text { a.s.l., } \\
38 \mathrm{~km} \text { southwest of Baoding city, Hebei province. Aerosol sam- } \\
\text { ples collected from an } 8 \mathrm{~m} \text {-tall building. }\end{array}$ \\
\hline $\begin{array}{l}\text { Jinsha (JS) } \\
\left(29^{\circ} 37.8^{\prime} \mathrm{N}, 114^{\circ} 12^{\prime} \mathrm{E}\right)\end{array}$ & $\begin{array}{l}\text { Rural station, } 416 \mathrm{~m} \text { a.s.1., } 105 \mathrm{~km} \text { north of Wuhan city, Hubei } \\
\text { province. Aerosol samples collected from an } 8 \mathrm{~m} \text {-tall building. }\end{array}$ \\
\hline $\begin{array}{l}\text { Lhasa (LS) } \\
\left(29^{\circ} 40.2^{\prime} \mathrm{N}, 91^{\circ} 7.8^{\prime} \mathrm{E}\right)\end{array}$ & $\begin{array}{l}\text { Rural station in remote area, } 3663 \text { ma.s.l., within Lhasa city, } \\
\text { Qinghai-Xizang Plateau. Aerosol samples collected from a sev- } \\
\text { eral meter tall building. }\end{array}$ \\
\hline $\begin{array}{l}\operatorname{LinAn}(\mathrm{LA}) \\
\left(30^{\circ} 18^{\prime} \mathrm{N}, 119^{\circ} 44^{\prime} \mathrm{E}\right)\end{array}$ & $\begin{array}{l}\text { Rural station, } 139 \mathrm{~m} \text { a.s.1., } 150 \mathrm{~km} \text { northeast of Shanghai, and } \\
50 \mathrm{~km} \text { west of Hangzhou city (Zhejiang province, China). } \\
\text { Aerosol samples collected from a } 10 \mathrm{~m} \text {-tall building. }\end{array}$ \\
\hline $\begin{array}{l}\text { Longfengshan (LFS) } \\
\left(44^{\circ} 43.8^{\prime} \mathrm{N}, 127^{\circ} 36^{\prime} \mathrm{E}\right)\end{array}$ & $\begin{array}{l}\text { Rural station, } 331 \mathrm{~m} \text { a.s.l., } 175 \mathrm{~km} \text { northeast of Harbin city. } \\
\text { Aerosol samples collected from a } 6 \mathrm{~m} \text {-tall building. }\end{array}$ \\
\hline $\begin{array}{l}\text { Nanning (NJ) } \\
\left(22^{\circ} 49.2^{\prime} \mathrm{N}, 108^{\circ} 21^{\prime} \mathrm{E}\right)\end{array}$ & $\begin{array}{l}\text { Urban station, } 84 \text { ma.s.l., in Nanning city, Guangxi province. } \\
\text { Aerosol samples collected from a } 97 \text { m-tall building. }\end{array}$ \\
\hline $\begin{array}{l}\text { Panyu (PY) } \\
\left(23^{\circ} 0^{\prime} \mathrm{N}, 113^{\circ} 21^{\prime} \mathrm{E}\right)\end{array}$ & $\begin{array}{l}\text { Urban station in Panyu district of Guangzhou city ( } 5 \mathrm{~m} \text { a.s.1.), } \\
\text { Guangdong province. Aerosol samples collected from a } 140 \mathrm{~m}- \\
\text { tall hill. }\end{array}$ \\
\hline $\begin{array}{l}\text { Shangri-La, Zhuzhang (SRL) } \\
\left(28^{\circ} 00^{\prime} \mathrm{N}, 99^{\circ} 43^{\prime} \mathrm{E}\right)\end{array}$ & $\begin{array}{l}\text { Remote station, } 3583 \mathrm{~m} \text { a.s.1., } 12 \mathrm{~km} \text { northeast of Shangri-La } \\
\text { county (Diqing area, Yunnan province, China) }\end{array}$ \\
\hline $\begin{array}{l}\text { Taiyangshan, Changde (TYS) } \\
\left(29^{\circ} 10.2^{\prime} \mathrm{N}, 111^{\circ} 42.6^{\prime} \mathrm{E}\right)\end{array}$ & $\begin{array}{l}\text { Rural station, } 563 \mathrm{~m} \text { a.s.1., } 18 \mathrm{~km} \text { northwest from Changde city, } \\
\text { Hunan province. Aerosol samples collected from an } 8 \mathrm{~m} \text {-tall } \\
\text { building. }\end{array}$ \\
\hline $\begin{array}{l}\text { Xian (XA) } \\
\left(34^{\circ} 25.8^{\prime} \mathrm{N}, 108^{\circ} 58.2^{\prime} \mathrm{E}\right)\end{array}$ & $\begin{array}{l}\text { Urban station in northern margin of Xian city, but within Jin } \\
\text { River Industrial District in the Guanzhong Plain, } 363 \mathrm{~m} \text { a.s.l., } \\
20 \mathrm{~km} \text { north of center of Xian city, Shaanxi province. Aerosol } \\
\text { samples collected from a } 4 \mathrm{~m} \text {-tall sampling container. }\end{array}$ \\
\hline $\begin{array}{l}\text { Zhengzhou (ZZ) } \\
\left(34^{\circ} 46.8^{\prime} \mathrm{N}, 113^{\circ} 40.8^{\prime} \mathrm{E}\right)\end{array}$ & $\begin{array}{l}\text { Urban station, } 99 \mathrm{~m} \text { a.s.l., in the center of Zhengzhou city, } \\
\text { Henan province. Aerosol samples collected from a } 56 \mathrm{~m} \text {-tall } \\
\text { building. Aerosol samples collected from a } \sim 5 \mathrm{~m} \text {-tall building. } \\
\text { Aerosol samples collected from a } 10 \mathrm{~m} \text {-tall building. }\end{array}$ \\
\hline
\end{tabular}




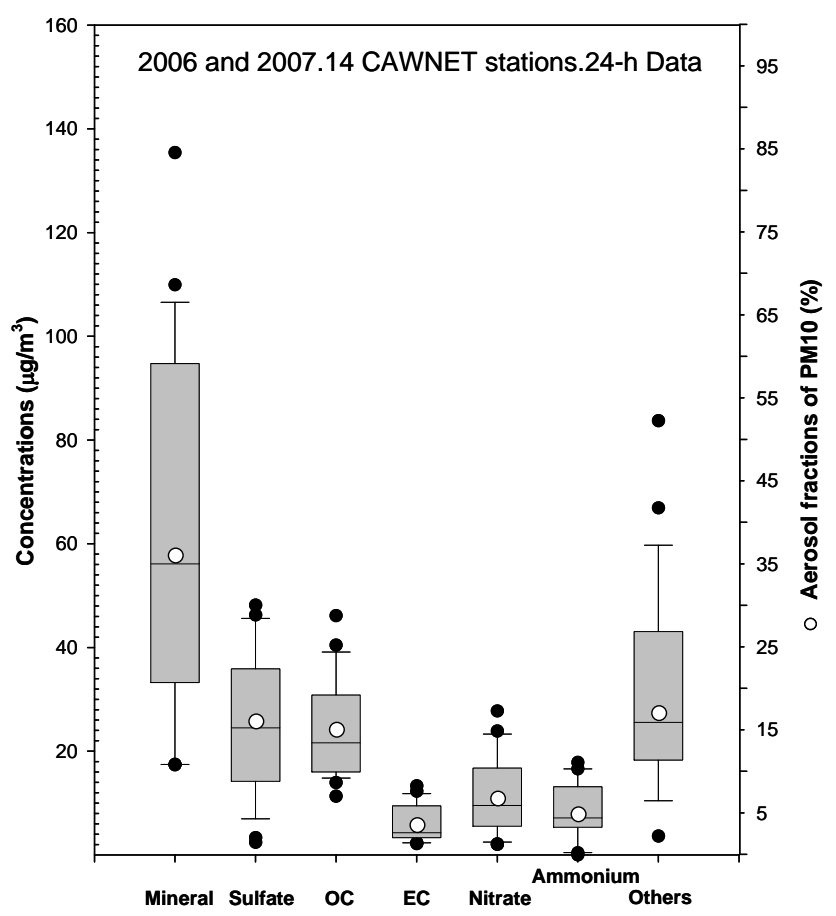

Fig. 2. Annual averaged mass concentrations (median of the box plot) of aerosol chemical species and its percentage (open circle) of $\mathrm{PM}_{10}$ in China. The bottom and up of the box plot represents $25 \%$ and $75 \%$ percentiles.

The $\mathrm{Al}_{2} \mathrm{O}_{3}$ target with a working energy of $50 \mathrm{keV}$ is deal for $\mathrm{Cd}, \mathrm{Sb}$ and $\mathrm{Ba}$ while the Co target has an energy range of $12.5 \mathrm{keV}$ for the analysis of $\mathrm{K}, \mathrm{Ca}, \mathrm{Ti}, \mathrm{V}, \mathrm{Cr}, \mathrm{Mn}$. The HOPG target's working tube voltage is $12.5 \mathrm{keV}$, which is good for $\mathrm{Na}, \mathrm{Mg}, \mathrm{Al}, \mathrm{P}, \mathrm{S}$ and $\mathrm{Cl}$. Eighteen elements, i.e. As, $\mathrm{Br}, \mathrm{Ca}$, $\mathrm{Cr}, \mathrm{Cu}, \mathrm{Fe}, \mathrm{K}, \mathrm{Mg}, \mathrm{Mn}, \mathrm{Na}, \mathrm{Ni}, \mathrm{Pb}, \mathrm{S}, \mathrm{Se}, \mathrm{Ti}, \mathrm{V}, \mathrm{Zn}$ and $\mathrm{Zr}$, were analyzed by the Multi-Channel Analyzer. A standard glass sample (Spectro Corp. Germany) was used to check the signal energy and the multi-channel twice a month. The standard calibration curve between the intensity of signal and the elemental concentration is determined by single-element Mylar filters (Dzubay et al., 1987). Seven blank quartz filters were analyzed with Mylar matrices method. The averaged background of blank filters was subtracted during spectral processing (Kellog et al., 1999).

After the XRF analysis, a portion of the filter samples was allocated for the determination of $\mathrm{SO}_{4}^{2-}, \mathrm{NO}_{3}^{-}, \mathrm{NH}_{4}^{+}$ and other ionic species, including $\mathrm{Na}^{+}, \mathrm{K}^{+}, \mathrm{Ca}^{2+}, \mathrm{Mg}^{2+}$, $\mathrm{F}^{-}$and $\mathrm{Cl}^{-}$by an ion chromatography (Dionex 600 series). The measurement technique used in this study is rather standard, which has been used in many network observations of $\mathrm{PM}_{10}$ around the globe (Wang and Shooter, 2001; Malm, and Schichtel, 2004; Bourotte et al., 2007; Querol et al., 2008). A paper on the measurement of $\mathrm{PM}_{10}$ chemical composition in China has been published (Zhang et al., 2002) for the same technique where the measurement limitations associated with filter sampling and storage has been discussed.

Thermal/optical reflectance carbon (TOR) analysis for EC and $\mathrm{OC}$ content was performed following the Interagency Monitoring of Protected Visual Environments (IMPROVE) protocol (Chow et al., 1993, 2004). The detailed procedures carried out at the LAC/CAMS can be found in reference (Zhang et al., 2005b). The measurement limitations associated with filter sampling and storage, especially those pertaining to the semi-volatile components, have been discussed in our previous work (Zhang et al., 2008a).

\section{Results and discussions}

In addition to the spatial and temporal distributions of aerosols in China, the analyses will also help to identify the source attributions and atmospheric processes that influence the air quality in China, especially the visibility, or haze problems. This session will present the general pictures of atmospheric aerosols in China, put them into the perspective of global aerosol distributions, and finally link them with the long term visibility observations in China.

\subsection{Aerosol chemical compositions in various areas of China and comparisons with global aerosol}

The annual averaged daily chemical data sets from the 16 stations in China are listed in Table 2. Generally, mineral aerosol (including sand dust, urban fugitive dust and coal ash) is the largest aerosol component in China, accounting for $\sim 35 \%$ of $\mathrm{PM}_{10}$ (Fig. 2 and Table 2) and even reaching from $50 \%$ to $60 \%$ in northwestern China. The mineral dust determination is achieved through the surrogate concentration of $\mathrm{Fe}$, which is around $4 \%$ in the Chinese mineral dust mass (Zhang et al., 1993, 1997, 2003). The annual median concentration of $\sim 55 \mu \mathrm{g} \mathrm{m}^{-3}$ for mineral aerosol alone (Fig. 2) is almost equivalent to the sum of all kind of aerosols in urban Europe (discussed in the later section), showing the substantial contributions of mineral aerosol to the relative high regional background of aerosol mass in China. The high mineral fraction is partially a result of the Asian desert sources mainly in Mongolia and in western and northern China such as the Taklimakan and Badain Juran deserts (Zhang et al., 1996, 2003), which are not far from most of northern part of China. On the other hand, some of high mineral concentrations are evidently caused by emissions from urban fugitive dust/fly ash sources, especially during nonspring seasons. For example, $\mathrm{Ca}$ is mainly associated with mineral aerosol in the $\mathrm{PM}_{10}$ samples; but non-crustal $\mathrm{Ca}$ is found in the coarse particle fraction, most of which is expected to be from construction activities and coal-ash (Zhang et al., 2002). 


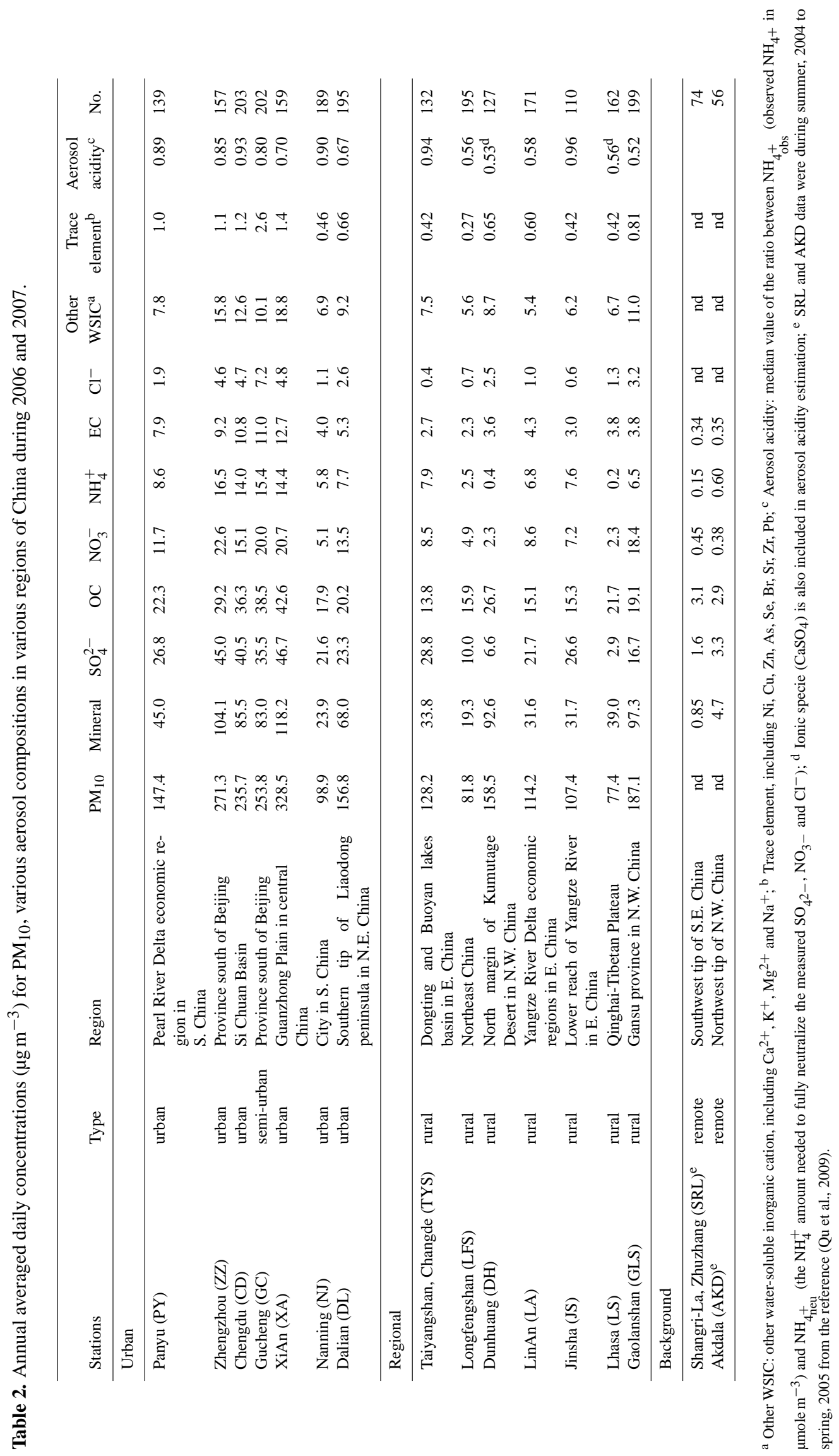




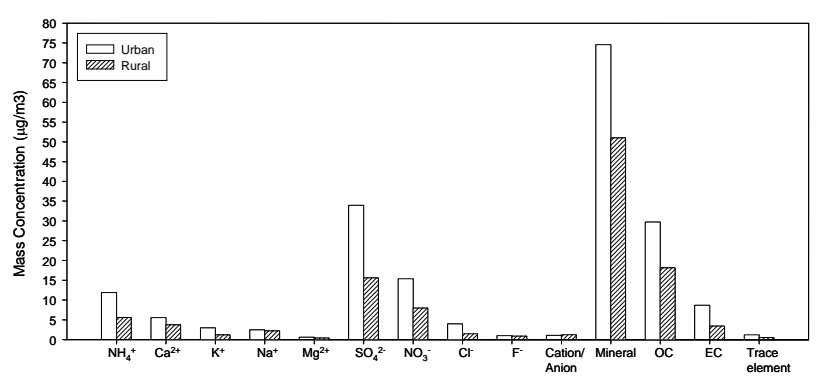

Fig. 3. Annual averaged mass concentrations of various chemical species in urban and rural aerosols in China. The balance between cations and anions (cation/anion) are expressed in microequivalents per cubic meter in this diagram.

Sulfate and OC are other two major components with light-scattering properties, with each accounting for $\sim 15 \%$ of total $\mathrm{PM}_{10}$ while nitrate and ammonium is about $7 \%$ and $5 \%$, respectively. But in the Qinghai-Xizang (Tibetan) Plateau and the desert in the northwestern areas, sulfate accounted for only about $3 \%-6 \%$ of the $\mathrm{PM}_{10}$, while OC in the proportion of these regions did not drop. The absorbing EC accounts for only $3.5 \%$ (Fig. 2). The sum of concentrations of other water-soluble inorganic cations (called "other WSIC" in Table 2), including $\mathrm{Ca}^{2+}, \mathrm{K}^{+}, \mathrm{Mg}^{2+}$ and $\mathrm{Na}^{+}$, are also listed. Trace elements ( $\mathrm{Ni}, \mathrm{Cu}, \mathrm{Zn}, \mathrm{As}, \mathrm{Se}, \mathrm{Br}, \mathrm{Sr}, \mathrm{Zr}$ and $\mathrm{Pb}$ ) and other WSIC account for $\sim 0.5 \%$ and $\sim 5 \%$ of $\mathrm{PM}_{10}$, respectively.

Referring to Fig. 3, the large difference between urban and rural aerosols were found for mass concentrations of various major chemical species, especially for $\mathrm{NH}_{4}^{+}, \mathrm{SO}_{4}^{2-}, \mathrm{NO}_{3}^{-}$ and EC with urban to rural ratios (called "urban impact" thereafter) of 2.1, 2.2, 1.9 and 2.6, respectively, exhibiting that the major sources of these constituents are mainly located in urban areas. Probably due to the long-rang transport of the Asian dust that has an equal impact to urban and rural mineral dust level, the urban to rural ratio for mineral aerosol is only $\sim 1.5$. The urban impact of $\mathrm{OC}, \sim 1.6$, is also relatively low, probably due to more biomass burning sources in rural area, and the existence of large SOC that was favored in regionally-dispersed aerosol (discussed in details later). The mass concentrations of rural $\mathrm{Ca}^{2+}, \mathrm{Na}^{+}, \mathrm{Mg}^{2+}$ are not much lower than urban values, showing a considerable number of soluble cations in rural aerosols, although their mass concentrations are not high.

In Fig. 4, the annual or seasonal mean mass concentrations of six major types of aerosols in $\mathrm{PM}_{10}$ are synthesized with at least one entire year data from various rural and urban sites in 16 kinds of regions over the world, to compare the aerosol chemical compositions of China with those of global aerosols.

\section{Primary aerosol species}

Mineral Aerosol generally is the largest component in most areas of the world (Fig. 4). The highest mass concentration levels are found in urban areas of S. Asia, HBP (Hua Bei Plain) in N. China and SCB (Si Chuan Basin) in S. W. China with mean value about $80-85 \mu \mathrm{g} \mathrm{m}^{-3}$. The rural area in N. W. China also has relative higher mineral concentrations of around $85 \mu \mathrm{g} \mathrm{m}^{-3}$. Mineral concentrations decrease in the urban areas of S. China, YRD (Yangtze River Delta), and rural areas of E. and N. E. China, High Asian Area (higher than $1680 \mathrm{~m}$ a.s.l) where concentrations are spatially uniform ranging from 20 to $40 \mu \mathrm{g} \mathrm{m}^{-3}$, exhibiting the relative higher regional background of mineral mass in whole Asian regions. Urban areas of S. E. Asia, US and Europe have lower mean mineral concentration of $\sim 10-20 \mu \mathrm{g} \mathrm{m}^{-3}$. In rural Europe and US the lowest concentrations, generally below $10 \mu \mathrm{g} \mathrm{m}^{-3}$, are found with few deserts and good vegetation cover. One should also note that the US values, mostly from Malm and Schichtel (2004), are for $\mathrm{PM}_{2.5}$, not $\mathrm{PM}_{10}$.

Organic Carbon has its highest mass concentrations in urban S. Asia with mean value of $\sim 66 \mu \mathrm{g} \mathrm{m}^{-3}$. Of the total OC aerosol, there are substantial amount attributable to primary emission. This is why the $\mathrm{OC}$ is discussed here in the primary aerosol group. In China, the OC mass concentrations are at level of $33-36 \mu \mathrm{g} \mathrm{m}^{-3}$ from urban of SCB and HBP to $\sim 15-20 \mu \mathrm{g} \mathrm{m}^{-3}$ in other regions. Unusually high OC, $\sim 25 \mu \mathrm{g} \mathrm{m}^{-3}$, is found in rural northwest China, urban S. Asia and High Asian Area, showing the possible influences of open biomass burning (Zhang et al., 2008a; Decesari et al., 2009; Stone et al., 2010). Of the total global OC emissions, about $74 \%$ is attributable to the biomass burning (Bond et al., 2004). On the basis of 2003 data, Asian OC emissions was estimated to be $9.2 \mathrm{Tg} \mathrm{C}$, of which China and India contributed $\sim 2.6$ and $\sim 2.2 \mathrm{Tg} \mathrm{C}$, respectively (Ohara et al., 2007). In addition, SOC also contributes to the total OC (Zhang et al., 2005b; Miyazaki et al., 2006; Sullivan et al., 2006; Weber et al., 2007; Zhang et al., 2008a). The estimated uncertainties of global annual SOC production are large, with a production rate ranging from 2.5 to $44.5 \mathrm{Tg} \mathrm{OM}$ per year from biogenic volatile organic compounds (VOC) and 0.05 to $2.6 \mathrm{Tg}$ OM per year from anthropogenic VOC (Tsigaridis and Kanakidou, 2003). OC concentrations are relatively lower in US and Europe, decreasing from urban mean $\sim 6.0 \mu \mathrm{g} \mathrm{m}^{-3}$ to rural level of $\sim 1.0-2.5 \mu \mathrm{g} \mathrm{m}^{-3}$.

Elemental Carbon is also called as black carbon (BC), which is the smallest fraction of major aerosol components in most parts of the world. But in urban S. Asia, High Asian Area and urban Europe, EC concentrations are higher than ammonium ion that is usually the second smallest aerosol component. The EC has its highest level of mass concentrations, $\sim 10 \mu \mathrm{g} \mathrm{m}^{-3}$, in urban S. Asia, HBP and SCB of China, decreases to $\sim 3.0-6.0 \mu \mathrm{g} \mathrm{m}^{-3}$ in other parts of China, urban S. E. Asia, and to $\sim 3.0 \mu \mathrm{g} \mathrm{m}^{-3}$ in urban US and Europe, and declines further to $\sim 0.2-2.0 \mu \mathrm{g} \mathrm{m}^{-3}$ from High Asian Area 


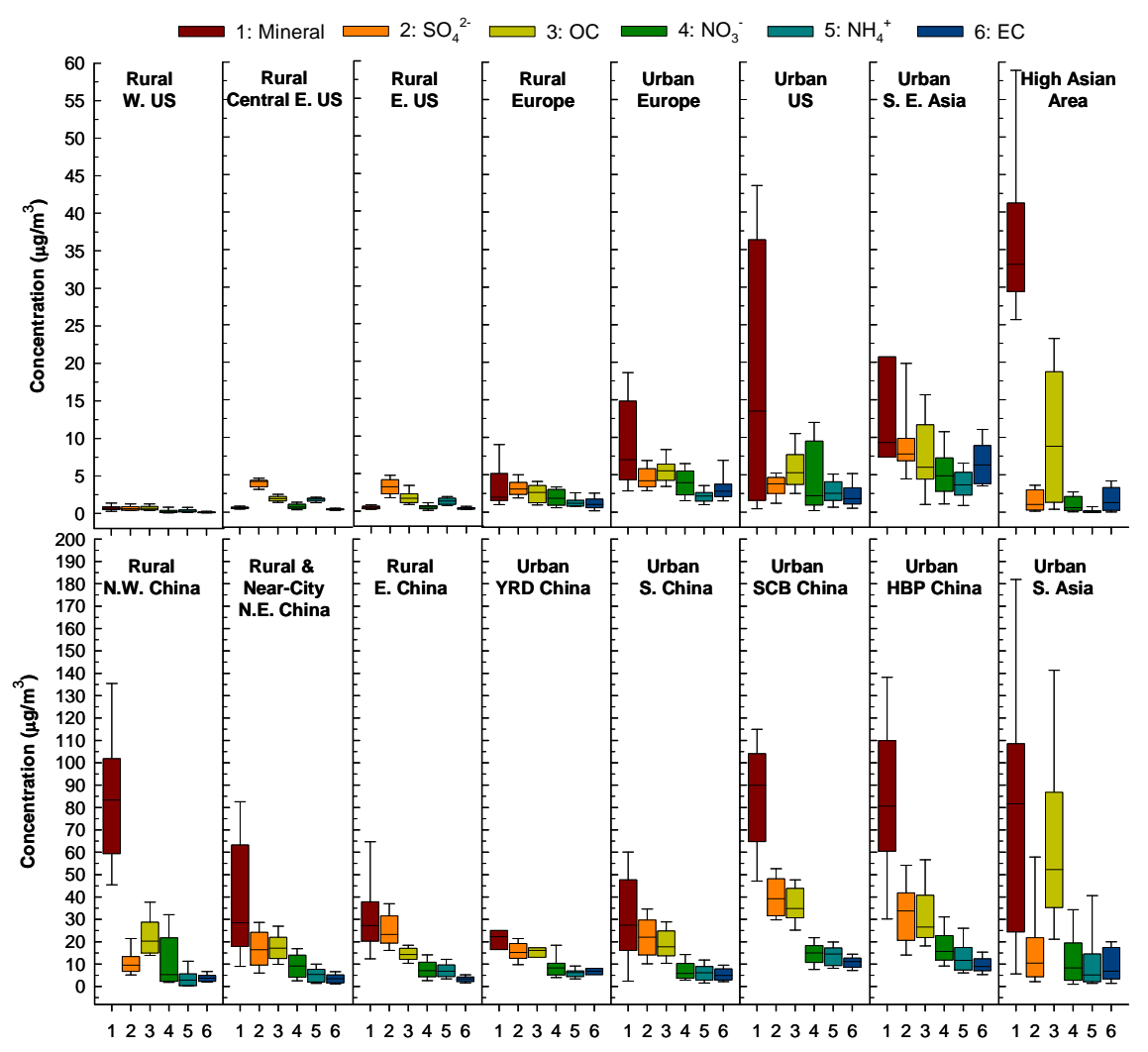

Fig. 4. Box plot summarized the annual, seasonal or monthly mean mass concentration $\left(\mu \mathrm{g} \mathrm{m}^{-3}\right)$ of six major types of aerosol particles in diameter smaller than 10 micron with at least an entire year data from various rural and urban sites in 16 areas of the world continental area. These include: (1) Rural W. US (Malm and Schichtel, 2004); (2) Rural Central E. US (Malm and Schichtel, 2004); (3) Rural E. US (Liu et al., 2005; Malm and Schichtel, 2004; Malm et al., 1994; Tanner et al., 2004); (4) Rural Europe (Gullu et al., 2000; Hueglin et al., 2005; Kocak et al., 2007; Putaud et al., 2004; Puxbaum et al., 2004; Querol et al., 2009; Querol et al., 2001; Rodríguez et al., 2004; Theodosi et al., 2010; Viana et al., 2008; Yin and Harrison, 2008; Yttri, 2007); (5) Urban Europe (Hueglin et al., 2005; Lenschow et al., 2001; Lonati et al., 2005; Perez et al., 2008; Putaud et al., 2004; Querol et al., 2008; Querol et al., 2001; Rodríguez et al., 2002; Rodríguez et al., 2004; Roosli et al., 2001; Viana et al., 2006; Viana et al., 2007; Yin and Harrison, 2008); (6) Urban US (Chow et al., 1993a; Ito et al., 2004; Kim et al., 2000; Liu et al., 2005; Malm and Schichtel, 2004; Sawant et al., 2004; Tanner et al., 2004); (7) Urban S. E. Asia (Kim et al., 2007b; Lee and Kang, 2001; Oanha et al., 2006); (8) High Asian Area, with mean height higher than $1680 \mathrm{~m}$ a.s.l (Decesari et al., 2009; Qu et al., 2009; Ram et al., 2010; Rastogi and Sarin, 2005; Shresth et al., 2000; This work); (9) Rural N. W. China (Zhang et al., 2008a; this work); (10) Rural and Near-City N. E. China (Zhang et al., 2008a; this work); (11) Rural E. China (Zhang et al., 2008a; This work); (12) Urban YRD (Yangtze River Delta) in E. China (Wang et al., 2003, 2006; Yao et al., 2002; Ye et al., 2003); (13) Urban S. China (Hagler et al., 2006; Zhang et al., 2008a; This work); (14) Urban SCB (Si Chuan Basin) in S. W. China (Zhang et al., 2008a; This work); (15) Urban HBP (Hua Bei Plain) in N. China (Hu et al., 2002; Oanha et al., 2006; Roosli et al., 2001; Wang et al., 2005; Yao et al., 2002; Zhang et al., 2008a; this work); (16) Urban S. Asia (Chakraborty and Gupta, 2010; Khare and Baruah, 2010; Kumar et al., 2007; Lodhi et al., 2009; Raman et al., 2010; Rastogi and Sarin, 2005; Safai et al., 2010; Stone et al., 2010).

to rural Europe and US. Currently, Asia and Africa are considered to be two major sources of EC emissions accounting for $\sim 39 \%$ and $\sim 25 \%$ of total emission, respectively (Bond et al., 2004).

\section{Secondary aerosol species}

Sulfate, as the second largest fraction of aerosol mass in some areas of the world (Fig. 4), finds the highest concentrations in China, generally varying at two levels, $34-40 \mu \mathrm{g} \mathrm{m}^{-3}$ at hot-spots from SCB to HBP, and $15-25 \mu \mathrm{g} \mathrm{m}^{-3}$ at other areas of China, which is similar to the level of $\sim 20 \mu \mathrm{g} \mathrm{m}^{-3}$ in urban of S. Asia, slightly higher than the S. E. Asian level of $\sim 10 \mu \mathrm{g} \mathrm{m}^{-3}$. Large amount of coal consumptions in China, not only from the industrial activities but also from residential heating in many relatively small cities and towns, is the main reason for the higher sulfate mass observed, which is consistent with the large $\mathrm{SO}_{2}$ emissions, e.g. north and east China (Cao et al., 2010; Lu et al., 2010). Of the total global $\mathrm{SO}_{2}$ emissions, $\sim 100-120 \mathrm{Tg}$, in 2000-2010, 


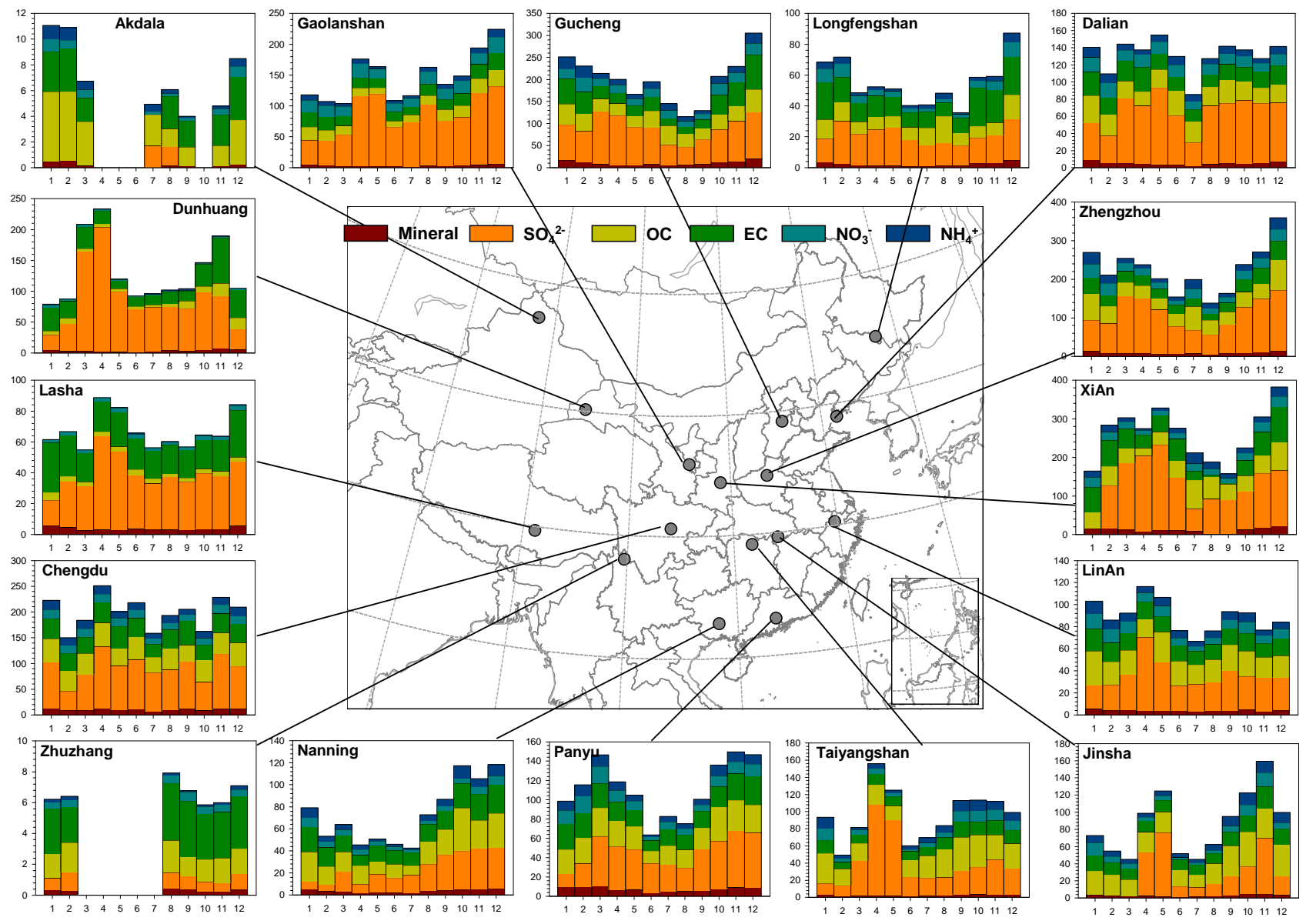

Fig. 5. Monthly averaged daily concentrations changes of aerosol chemical species in various regions of the CAWNET network.

emissions from coal-power plants account for $\sim 47 \%$. The major sources of current global emissions are also considered to be in Asia, especially in China, India and other emerging industry countries, where the total emission was around 47.0 Tg in 2006 .(Zhang et al., 2009a). Europe and America have lower emissions. This is why the relative lower sulfate concentrations are found between $1.0-4.0 \mu \mathrm{g} \mathrm{m}^{-3}$ from $\mathrm{Eu}-$ rope to most of areas of US.

Nitrate usually is the fourth largest aerosol species in most regions of the world (Fig. 4). Not surprisingly, nitrate tends to be highest around urban HBP, SCB in China, plus urban S. Asia with mean concentrations around $13-18 \mu \mathrm{g} \mathrm{m}^{-3}$, where ammonium and nitrogen oxide emissions are greatest (Cao et al., 2010; Ohara et al., 2007; Streets et al., 2003; Zhang et al., 2009a). The global emission inventory suggests the major sources for nitrogen oxide are from fossil fuel combustion, in which the emissions from coal- power plant and motor-vehicle are $\sim 22 \%$ and $41 \%$, respectively. The total global emission of 2000-2010 was estimated to be $\sim 80$ $110 \mathrm{Tg}$, a slight increasing over the previous century ${ }^{1}$. The

\footnotetext{
${ }^{1}$ Emission Database for Global Atmospheric Research,
}

world's largest emissions are reported from China, $\sim 20.8 \mathrm{Tg}$ in 2006 (Zhang et al., 2009a), followed by the United States, $\sim 14.9$ Tg in 2005. Outside the hot-spots area in China, nitrate mean concentrations are between $\sim 6.0-10 \mu \mathrm{g} \mathrm{m}^{-3}$. Urban US, Europe and S. E. Asia also have a similar or lower level of $\sim 5.0 \mu \mathrm{g} \mathrm{m}^{-3}$, while areas in High Asian Area, rural Europe and US have the averaged nitrate concentrations of around $1.0-2.0 \mu \mathrm{g} \mathrm{m}^{-3}$.

Ammonium is contributed mainly from coal-combustion of both industry and domestic consumptions, especially in China (Cao et al., 2010). While domestic animals, use of synthetic $\mathrm{N}$ fertilizers, biomass burning, human activities and pets are other major contributors to ammonium (Cao et al., 2010). The mean concentrations generally vary at a level, $12-14 \mu \mathrm{g} \mathrm{m}^{-3}$ in urban S. Asia, HBP, SCB of China, and at another level of $4.0-7.0 \mu \mathrm{g} \mathrm{m}^{-3}$ in other areas of China and urban S. E. Asia, which is bit higher than the levels of 2 $3 \mu \mathrm{g} \mathrm{m}^{-3}$ in urban US and Europe, 0.2-1.3 in rural US, Europe and High Asian Area (Fig. 4).

www.mnp.nl/edgar; The Greenhouse Gas and Air Pollution Interactions and Synergies,http://gains.iiasa.ac.at. 

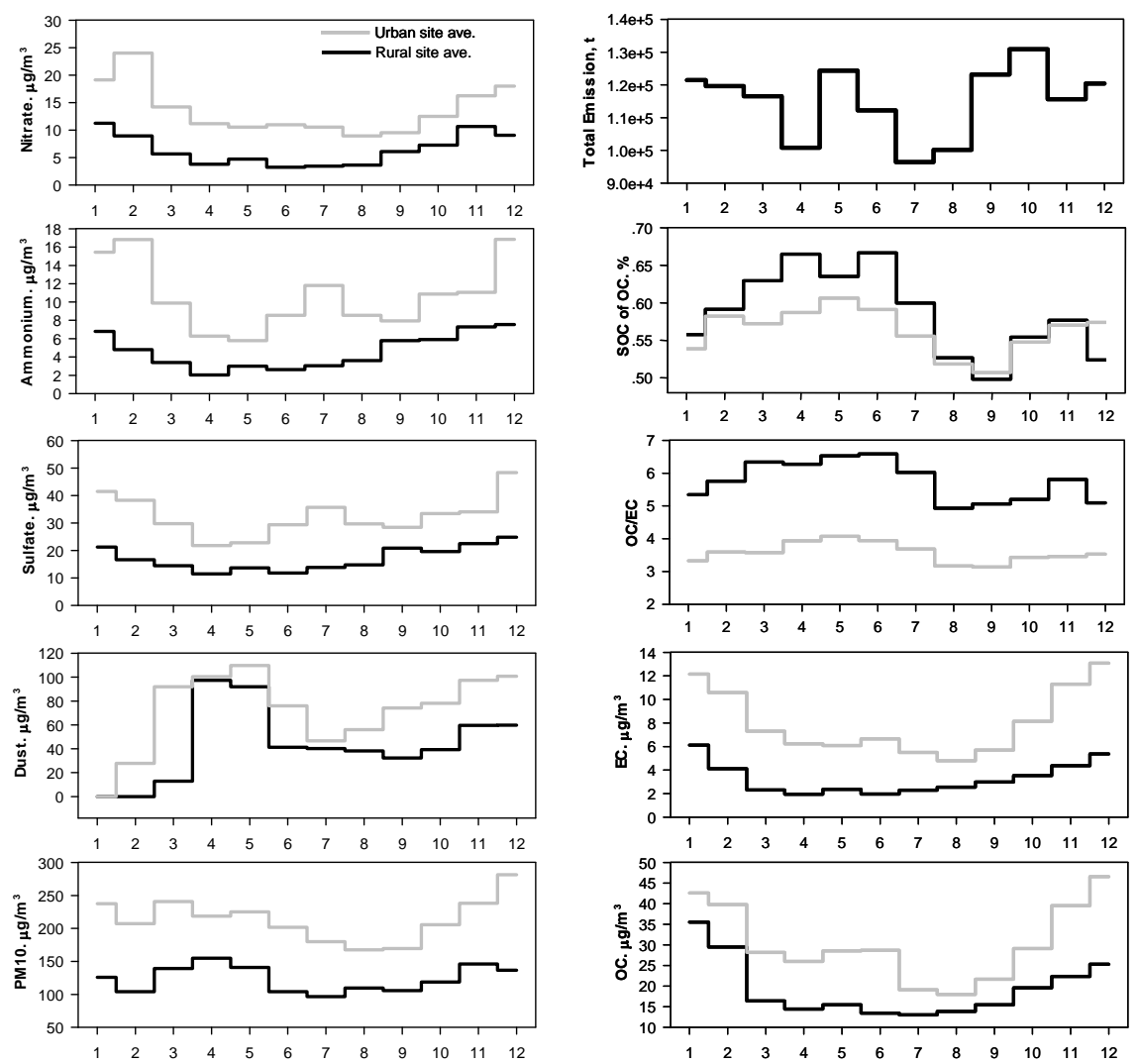

Fig. 6. Monthly changes of urban and rural mean concentrations of various aerosol species in China, also including the monthly variations of total aerosol and its precursor emission data.

\subsection{Seasonal patterns of aerosol chemical species in China}

The spatial variability in the seasonal patterns of each of the major aerosol types is explored (Fig. 5). In general, the bulk $\mathrm{PM}_{10}$ mass concentrations tend to be higher during the winter half year from the autumn to winter (14 of the 16 CAWNET sites) and lower in summer, having a secondary peak in spring (11 of the 16). In wintertime large amount of coal consumptions, especially from residential heating (Cao et al., 2010; Lu et al., 2010), is the main reason for the highest sulfate and other chemical species observed. Spring sand and dust storm (SDS) contributes a lot to tropospheric aerosol. In China the emissions of OC, VOC, $\mathrm{EC}, \mathrm{CO}, \mathrm{NH}_{3}, \mathrm{NO}_{\mathrm{x}}$ and PM have two peaks in May to June and October after wheat and food crops harvests, respectively, associated with the increase of biomass burning, fertilizer and other agricultural activities (Fig. 6). This is the reason why the bulk aerosol mass shows a general seasonal variation pattern with a peak in winter, dropping and then increasing in spring, reaching a minimum in summer and then increasing in autumn. The following sites had winter maxima: Longfengshan, Zhengzhou, XiAn, Jinsha, Nanning, Akdala, Gaolan- shan and Gucheng. Autumn maxima found in Jinsha, Panyu and Dunhuang. Spring maxima occurred in LinAn, Taiyangshan, Lasha, Dunhuang. But in the SCB (Chengdu) there is no obvious seasonal variation found. This is also true for Lasha in High Asian Area (Fig. 5). The seasonal variation for each component of Chinese aerosols is depicted as follows:

\section{Primary aerosol species}

Mineral Aerosol: Monthly mean concentrations of mineral aerosol over various CAWNET sites (Fig. 5) and its changes averaged for urban and rural sites (Fig. 6) illustrate that the relative higher concentration levels are found in Spring (March, April and May), reflecting the influences of Asian SDS (Zhang et al., 2003; Gong et al., 2006). The mineral concentrations then decline from June to Aug., and rise from September to December to the level similar to Spring's, especially for urban mineral aerosol, showing the contribution from the urban coal-ash and other fugitive dust during heating season from mid-autumn to winter. The rural mean concentrations of mineral aerosol change moderately, but remain similar to the urban ones. 
Organic Carbon: Like the discussion of OC concentrations in Sect. 3.1, its seasonal variation discussion is also addressed in the primary aerosol group. The monthly mean OC at urban and rural sites varies similarly (Fig. 6), with the highest level in winter, continuously declining in the thereafter months, increasing its mean concentration in May to June, dropping again and remaining the minimum level during summer, and then gradually rising from October to winter. This monthly changing pattern not only reflects the maximum winter emissions from fossil fuel combustions but also reveals the peak emissions associated with the agricultural activities from May to June and October in China. It can be seen that the seasonal variation of $\mathrm{OC}$ is most similar to the total emission pattern over China (Fig. 6) (Cao et al., 2006).

Elemental Carbon: The time series of monthly concentrations for EC are generally similar to the OC both for urban and rural data (Fig. 6), exhibiting a typical monthly and seasonal pattern like OC, showing a common source for these two components.

\section{Secondary aerosol species}

Sulfate: Generally, the changing pattern of monthly sulfate is similar to that of carbonaceous aerosols (Fig. 5), but the biggest difference appears in summer with a secondary peak. The monthly sulfate, especially at urban sites, increases its concentration from June and reaches its second peak in July (Fig. 6). This is probably due to plenty of $\mathrm{SO}_{4}^{2-}$ and gasphase $\mathrm{NH}_{3}$ in urban area, enhancing the photochemistry and lowering the air mass ventilation on a regional scale. The less varied change of rural sulfate shows again that the urban impact does not greatly extend over the rural areas in China.

Comparing urban and rural aerosol species, overall, the relative higher (Fig. 4) monthly mean concentrations of various aerosol species at urban sites varied similarly with those at rural sites (Fig. 6). The differences are enlarged normally during winter for most of the aerosol species, exhibiting urban emission impact in winter. As for sulfate and ammonium, however, the significantly increased gap between urban and rural mean is found in July, showing the summer influence on these secondary aerosol formation, especially for sulfate and ammonium products (Fig. 6).

Ammonium: The monthly changes of ammonium for urban and rural average are similar to sulfate but not to nitrate (Fig. 6), showing the evidences to support that the neutralization of acidic sulfate is favored over the formation of ammonium nitrate.

Nitrate: Unlike sulfate and ammonium which go up in July, nitrate and OC share a similar monthly changing pattern (Figs. 5 and 6), especially in urban area, indicating a common motor-vehicle source influences on them. After $\sim 300000$ heavy-emission vehicles were banned during 1 to 19 July of 2008 before the Beijing 08 Olympic Game (8-24 August of 2008), organics and nitrate concentrations were reduced by
$25-40 \%$, while the sulfate and ammonium basically changed very little. After further cutting the traffic by half from 20 July to 7 August at Beijing area, the concentration of organics and nitrate particles further decreased by $\sim 6-20 \%$ with little change in sulfate and ammonium (Zhang et al., 2009b). This suggests that the motor vehicle-related fossil fuel combustion is still the dominant source of nitrate and $\mathrm{OC}$ at Chinese urban cities. Because the neutralization of acidic sulfate is favored over the formation of ammonium nitrate, less ammonium nitrate can be formed due to insufficient $\mathrm{NH}_{3}$ left in summer. That is why no secondary peak was observed for nitrate in summer as for sulfate and ammonium. Generally, ammonium nitrate is formed in areas characterized by high $\mathrm{NH}_{3}$ and $\mathrm{HNO}_{3}$ concentrations and low temperatures (Pathak et al., 2004).

\subsection{Aerosol chemical signatures}

\subsubsection{Aerosol acidities}

The calculated ion balances for urban and rural aerosols show that in most cases the imbalance between cations and anions are less than several percent of the ionic budget (Fig. 3). The ion balance calculation is based on the following equations for anions (1) and for cations (2):

$$
\begin{aligned}
\text { Anion equivalence } & =\left(\mu \text { mole } \mathrm{m}^{-3}\right) \\
& =\left[\mathrm{F}^{-}\right]+\left[\mathrm{Cl}^{-}\right]+\left[\mathrm{NO}_{3}^{-}\right]+2\left[\mathrm{SO}_{4}^{2-}\right]
\end{aligned}
$$

$$
\begin{aligned}
\text { Cation equivalence }\left(\mu \text { mole } \mathrm{m}^{-3}\right)= & {\left[\mathrm{Na}^{+}\right]+\left[\mathrm{NH}_{4}^{+}\right] } \\
& +\left[\mathrm{K}^{+}\right]+2\left[\mathrm{Ca}^{2+}\right] \\
& +2\left[\mathrm{Mg}^{2+}\right]
\end{aligned}
$$

Among the cations, the most abundant mass is found to be $\mathrm{NH}_{4}^{+}$, followed by $\mathrm{Ca}^{2+}$ (Fig. 3). The mass concentrations of $\mathrm{K}^{+}, \mathrm{Mg}^{2+}$ and $\mathrm{Na}^{+}$are not high. Of the anions, $\mathrm{SO}_{4}^{2-}$ and $\mathrm{NO}_{3}^{-}$are the dominant species contributing to the aerosol acidities, both of which correlate highly with $\mathrm{NH}_{4}^{+}$and poorly with $\mathrm{Ca}^{2+}$ and $\mathrm{K}^{+}$, especially in urban area (Fig. 7) while the role of $\mathrm{Cl}^{-}$is minor, with less correlation with $\mathrm{NH}_{4}^{+}$. Furthermore, the relatively higher correlations are found between $\mathrm{SO}_{4}^{2-}, \mathrm{NO}_{3}^{-}$and $\mathrm{NH}_{4}^{+}$in urban than in rural areas. The correlations between $\mathrm{SO}_{4}^{2-}$ and $\mathrm{NH}_{4}^{+}$are higher than between $\mathrm{NO}_{3}^{-}$and $\mathrm{NH}_{4}^{+}$(Fig. 7), indicating again that ammonium sulfate is probably the predominant ammonium product in aerosols for both urban and rural areas in China.

In three major economic developmental areas, BeijingTianjin Area, the Yangtze River Delta Area, and the Pearl River Delta Area, waste and coal consumption accounts for $\sim 67 \%$ to $85 \%$ total $\mathrm{NH}_{3}$ emissions, of which people and 

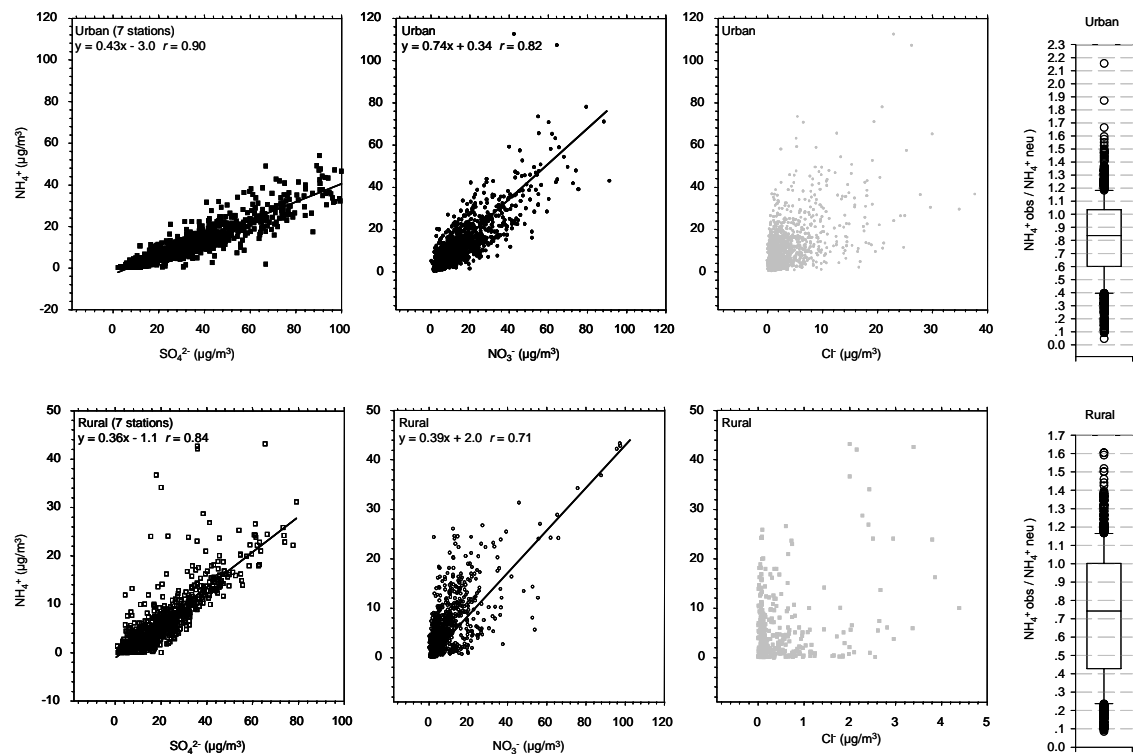

Fig. 7. Correlations among $\mathrm{NH}_{4}^{+}, \mathrm{SO}_{4}^{2-}, \mathrm{NO}_{3}^{-}$and $\mathrm{Cl}^{-}$, as well as aerosol acidities estimation.

poultry wastes, and coal-combustion from industry, commercial and residential usage are the major contributors in urban areas (Cao et al., 2010). In the rural area, the major source of ammonia emissions is from the agricultural activities, which accounts for $\sim 14 \%$ to $28 \%$ total $\mathrm{NH}_{3}$ emissions, with the nitrogen fertilizer as the major contributor (Cao et al., 2010). This is why one observed relative higher ammonium in urban than in rural sites, and why the relatively higher correlations are found between $\mathrm{SO}_{4}^{2-}, \mathrm{NO}_{3}^{-}$and $\mathrm{NH}_{4}^{+}$in urban than in rural areas.

Although the poor correlations between $\mathrm{SO}_{4}^{2-}$ and $\mathrm{Ca}^{2+}$ and $\mathrm{K}^{+}$are found in urban areas, a relative higher correlation is found between $\mathrm{SO}_{4}^{2-}$ and $\mathrm{K}^{+}$in rural area with a very small slope (0.062) (Fig. 8), showing some combinations between $\mathrm{K}^{+}$and $\mathrm{SO}_{4}^{2-}$ under the condition of low $\mathrm{NH}_{3}$ levels. Because of the very low concentration of $\mathrm{K}^{+}\left(\sim 1 \mu \mathrm{g} \mathrm{m}^{-3}\right)$ in rural area, the impact to aerosol acidities resulted from depleting $\mathrm{K}^{+}$by $\mathrm{SO}_{4}^{2-}$ can be negligible. However in rural area, especially in remote Duhuang (DH) and Lasha (LS) (Fig. 8), the relationship between $\mathrm{SO}_{4}^{2-}$ and $\mathrm{Ca}^{2+}$ is significantly different from other rural sites, exhibiting relative stronger neutralization of acidic sulfate by $\mathrm{Ca}^{2+}$ in these remote sites with very low $\mathrm{SO}_{4}^{2-}, \mathrm{NH}_{4}^{+}$mass and relative higher mass of $\mathrm{Ca}^{2+}$. Ionic species $\left(\mathrm{CaSO}_{4}\right)$ is taken into aerosol acidity estimation (Nenes et al., 2011) for Dunhuang and Lasha in Table 2.

The comparisons between observed $\mathrm{NH}_{4}^{+}$mass concentration (named " $\mathrm{NH}_{4_{\mathrm{obs}}^{+}}$") and the $\mathrm{NH}_{4}$ amount needed to fully neutralize the measured $\mathrm{SO}_{4}^{2-}, \mathrm{NO}_{3}^{-}$and $\mathrm{Cl}^{-}$(called " $\mathrm{NH}_{4_{\text {neu }}^{+}}$") are presented in right panel of Fig. 7. The annual median values of these data at each site are presented in
Table 2. The aerosol acidity is evaluated by comparing the ratio between $\mathrm{NH}_{4}^{+}$obs and $\mathrm{NH}_{4}^{+}$. . Particles are "more acidic" if the observed ammonium is significantly lower (by $25 \%$ and beyond (Zhang et al., 2005a)) than the predicted values, and are neutralized if the two values are close. Normally most of the median values of aerosol acidity larger than " 0.75 " are found at urban sites, expect for XiAn and Dalian, and the lower values found at rural sites, except for Changde and Jinsha. The observed $\mathrm{NH}_{4}^{+}$is generally about $84 \%$ and $74 \%$ of the neutralized $\mathrm{NH}_{4}^{+}$mass, for urban and rural aerosol, respectively, suggesting somewhat acidic for rural aerosol and the existence of the extra $\mathrm{SO}_{4}^{2-}$ and other anion molecules in the particles in the form of bisulfate $\left(\mathrm{HSO}_{4}^{-}\right)$or others in rural areas. Referring to Table 2, the ratio of $\mathrm{NH}_{4}^{+}$obs and $\mathrm{NH}_{4_{\text {neu }}^{+}}$ at Xian is relative lower than the "normal" urban value, probably due to the relative higher $\mathrm{SO}_{4}^{2-}$ found in the Guanzhong Plain (XiAn) where the high coal-combustion emission and higher sulfate concentrations were observed (Zhang et al., 2002). The $\mathrm{NH}_{4}^{+}$concentration finds non-proportionally low at Dalian, probably resulting from the abnormal lower ratio of $\mathrm{NH}_{4}^{+}$and $\mathrm{NH}_{4} 4_{\text {neu }}^{+}$. The extraordinary low ratio of $\mathrm{NH}_{4}^{+}$ and $\mathrm{NH}_{4 \text { neu }}^{+}$was found in relatively remote sites such as Dunhuang and Lhasa with less anthropogenic activities, probably due to the very low $\mathrm{NH}_{4}+$ concentrations measured around the detection limits of the instrument.

\subsubsection{Secondary organic carbon (SOC)}

In order to assess the overall spatial and temporal proportions of SOC in OC for better parameterizing the SOC in models, the monthly averaged SOC of total OC are presented 

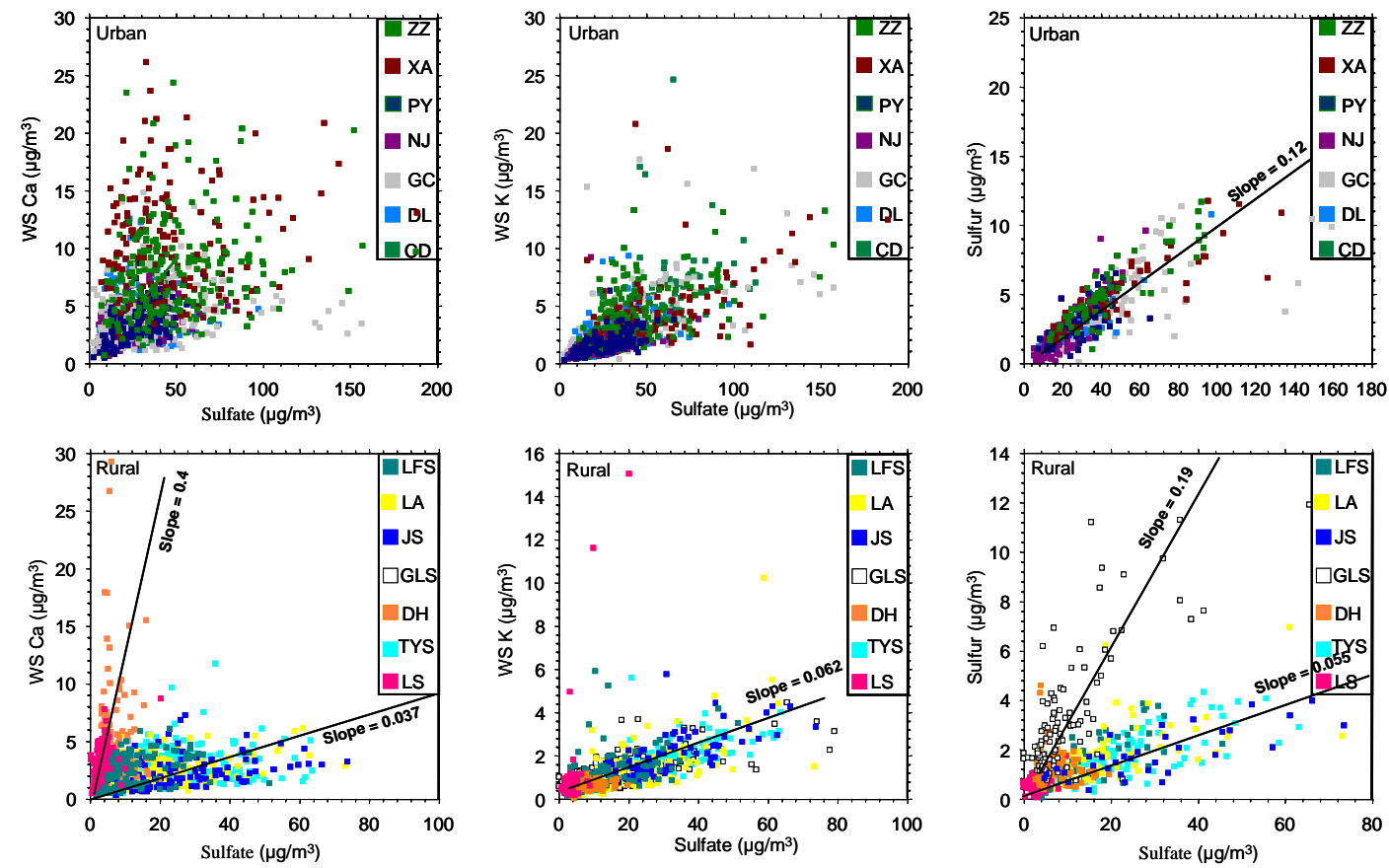

Fig. 8. Correlations among sulfate, water soluble $\mathrm{Ca}$ and $\mathrm{K}$ for urban and rural aerosols in China.

in Table 3, associated with $\mathrm{OC}$ to $\mathrm{EC}$ ratios. According to previous researches (Castro et al., 1999), the contribution of $\mathrm{SOC}$ is estimated from the following equation:

$\mathrm{SOC}=\mathrm{OC}_{\text {total }}-\mathrm{EC} \times(\mathrm{OC} / \mathrm{EC})_{\min }$

where SOC is the secondary $\mathrm{OC}, \mathrm{OC}_{\text {total }}$ denotes the total $\mathrm{OC}$, and $(\mathrm{OC} / \mathrm{EC})_{\min }$ is the minimum OC/EC ratio observed, which has a unique value identified for each site.

Consistent with the previous evaluation of OC and EC in 2006 from CAWNET (Zhang et al., 2008a), the two year data from 2006 to 2007 also show a relative higher OC/EC value of $\sim 5.5$ in rural aerosols, and a lower urban one of 3.5 that is similar to the ratios of emission inventories in China. The OC/EC ratios is 2.0 for fossil fuel combustion, 1.4 for gasoline and 3.0 for diesel oil, and 3.3 for biomass fuel combustion on the basis of the China emission inventory (Cao et al., 2006). This reflects the domination of primary emissions to the urban carbonaceous aerosol, especially from fossil and biomass fuel combustions. This lower ratio in urban areas can also be explained by the lower biomass burning emissions in urban areas.

The high OC/EC ratios of $\sim 5.5$ for rural aerosols are probably contributed from open biomass burning in fields, which has a calculated OC/EC ratio of 7.1 in the emission inventory (Cao et al., 2006). Referring to the monthly changes of OC/EC in Fig. 10, the OC/EC ratios peak in June and October, especially for rural aerosols due to the increasing influence of primary emission and precursors in June and October as described in previous section (Cao et al., 2010). The high
$\mathrm{OC} / \mathrm{EC}$ ratios can also be contributed from SOC formation in rural areas (Zhang et al., 2008a) as a noticeable rise of the SOC was estimated in June and October (Fig. 6). This is why the relative lower SOC percentage is not observed in summer as expected. The annual averaged fractions of SOC estimation show that the contributions from SOC to OC concentrations are $\sim 56 \%(52-64 \%)$ for the urban aerosols and $\sim 58 \%$ (35-82\%) for the regionally representative aerosols (Table 3). Despite its importance, the formation processes of SOC are highly uncertain, and the lack of a quantitative understanding of secondary organic formation processes in the atmosphere is one of the most important weaknesses in the present understanding of atmospheric aerosol and its climate effect (Hallquist et al., 2009; Tsigaridisa and Kanakidou, 2007). Although this work presents a very rough estimate for SOC with uncertainty, it still can provide some insight into the SOC contributions to the total OC.

\subsubsection{Regional haze distributions and classifications in China}

As a result of the increasing aerosol concentrations in China, the air quality has been deteriorating for a couple of decades, associated especially with the increasing hazy weathers. However, there was no systematic monitoring network for aerosols in China to quantify the trend. As the visibility is a good indicator of aerosol loadings in the atmosphere, the analysis of the visibility can provide some estimates of the aerosol trends in China. 


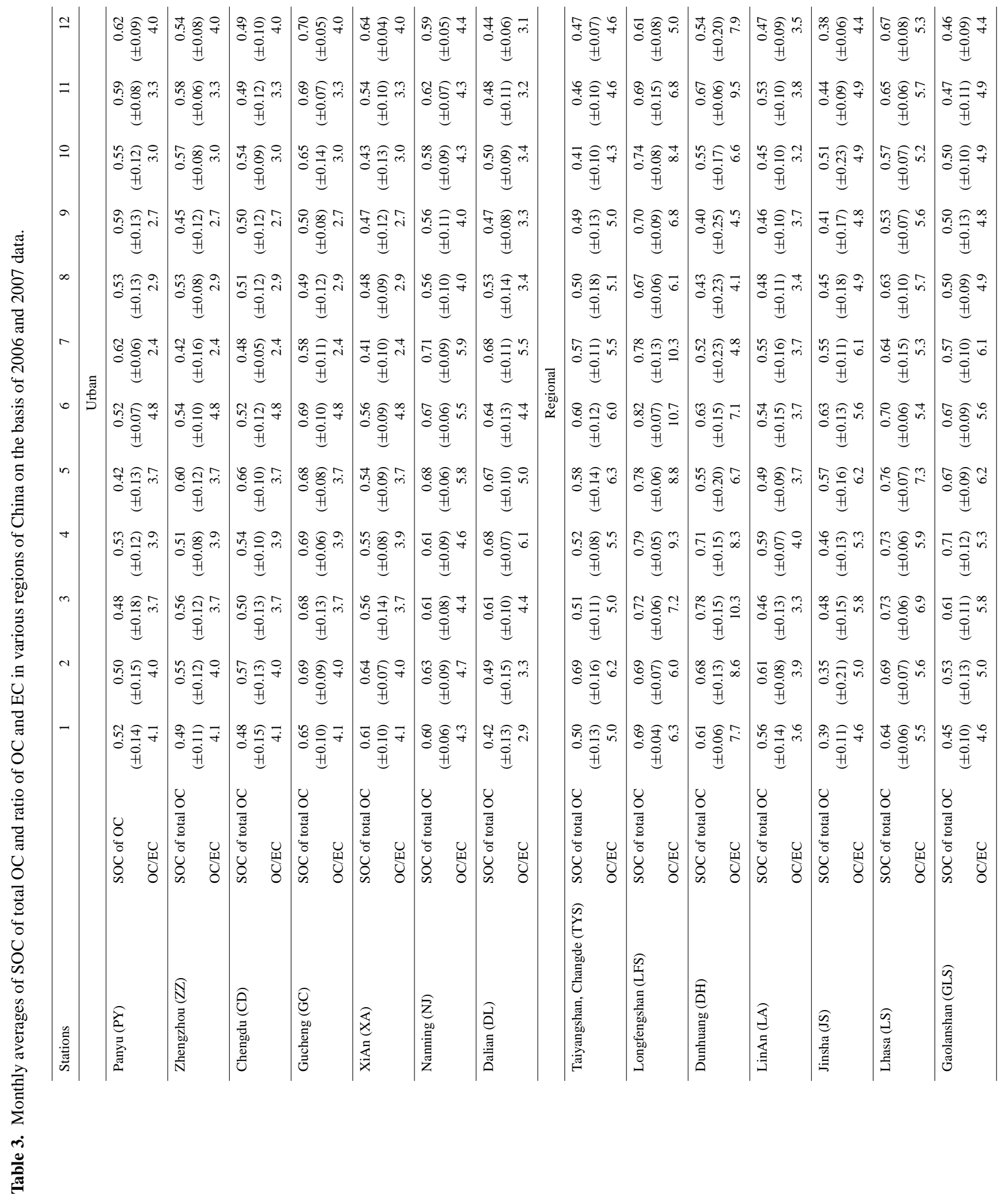

要




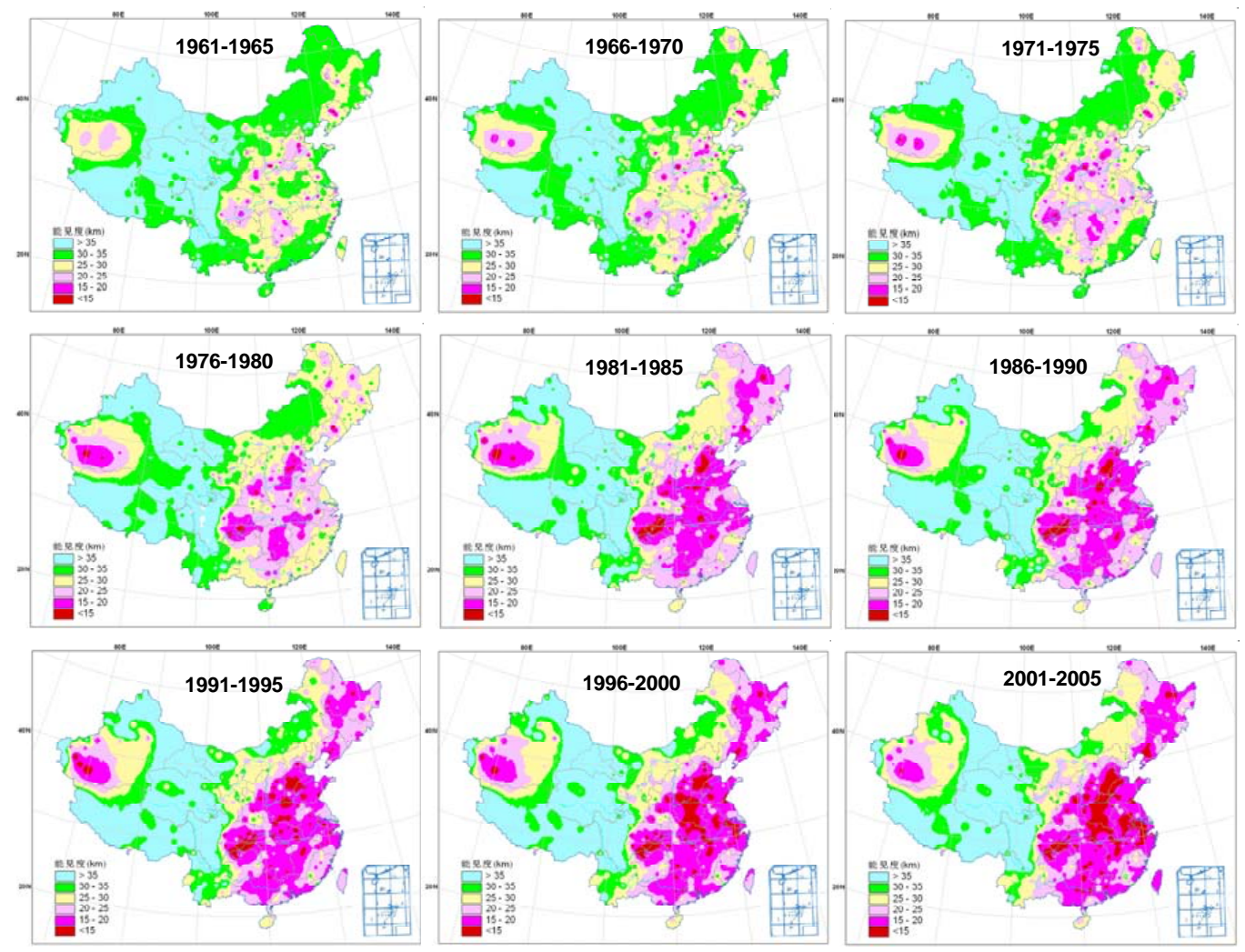

Fig. 9. Every five year mean visibility changes since 1960 .

Based on the 14:00 (Beijing Time) surface visibility data from 681 meteorological stations in China from 1957 to 2005, excluding the data for rainy, snowy, foggy, misty, and sand and dust storm days, the regional haze distributions and its trend every five years are illustrated in Fig. 9. With less anthropogenic influences before 1980's, few areas have mean surface visibility less than $15 \mathrm{~km}$. Eastern China was the low visibility region with $\sim 25-30 \mathrm{~km}$ annual mean visibility.

Based upon above visibility data, the temporal and spatial distribution of visibility are used to find the regions with similar visibility trends by rotated empirical orthogonal function (REOF) method (Fig. 10). The REOF can resolve the principal component of the visibility data on the basis of their temporal and spatial variations, and identify the distributions of high correlating area of each principal (called mode in Fig. 10). Nine regions with similar visibility trends were found with some sub-regions (Fig. 11a).

- Region I: i.e. N.E. China, with two sub-regions: one is in the major grain producing areas $\left(\mathrm{I}_{(1)}\right)$ mainly in Heilongjiang Province; another is in old industrial base (I $\left.{ }_{(2)}\right)$ mainly in Liaoning province.

- Region II: i.e. Hua Bei Plain (HBP) in N. China, including one of the China's rapid economic development regions, Beijing-Tianjin area, as well as the provinces of Hebei, Shangdong and Henan. The Guanzhong Plain in the south of the Loess Plateau (II ${ }_{(2)}$ ) is also assigned into this region, mainly because of the similar visibility change.

- Region III: i.e. E. China, including another rapid economy development region, the Yangtze River Delta area and the provinces of Hubei, Anhui, Jiangsu, Shanghai, Zhejiang, Hunan and Jiangxi.

- Region IV: mainly including Fujian Province and southeast hilly area of China.

- Region V: i.e. S. China, including the third major rapid economic development region, the Pearl River Delta area, and the provinces of Guangdong and Guangxi.

- Region VI: i.e. S.W. China, including the Si Chuan Basin (SCB).

- Region VII: i.e. southwest of the Yunnan-Guizhou Plateau.

- Region VIII: i.e. High Asian Area, including the main area of the Qinghai-Xizang (Tibetan) Plateau.

- Region IX: i.e. N.W. desert areas, including Gobi and arid areas with several sub-regions. 


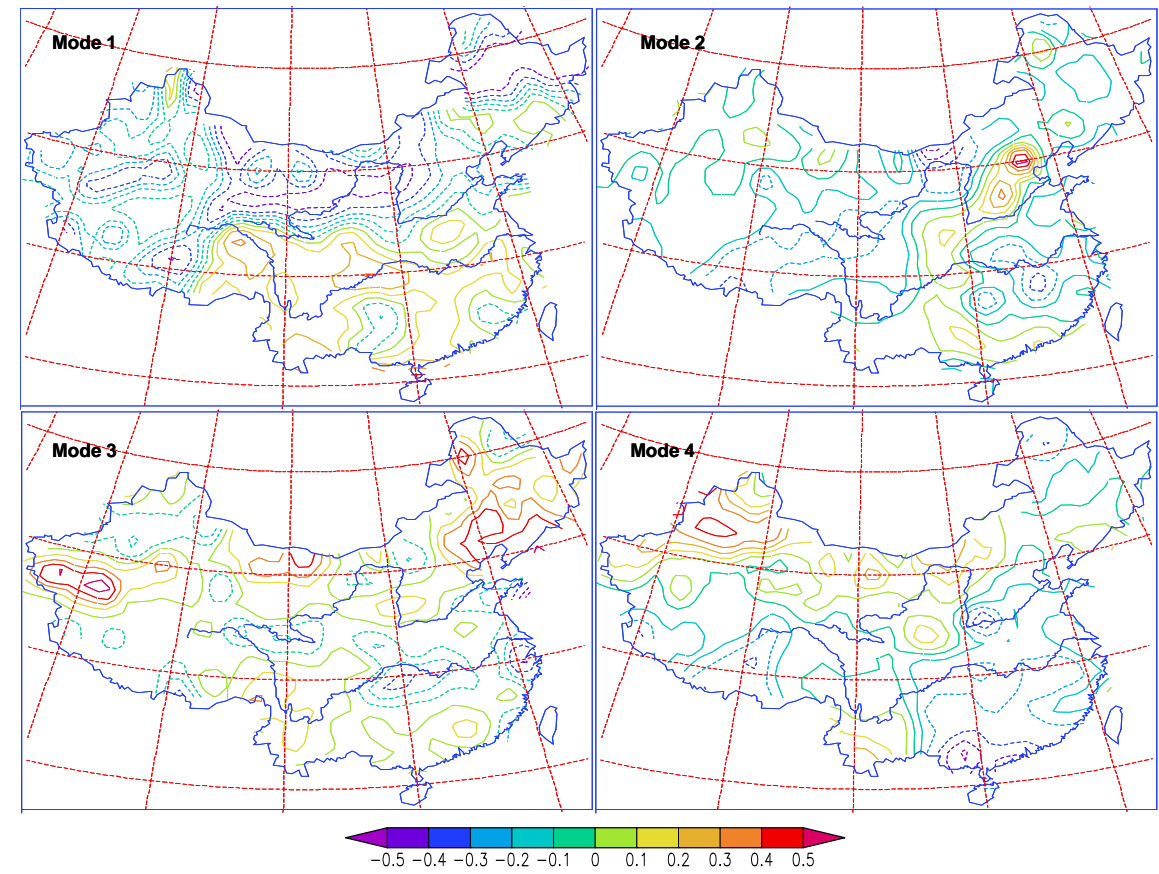

Fig. 10. Visibility mode (principal component) coefficient distributions that resolved by REOF method on the basis of 14:00 surface visibility data from 681 meteorological stations in China during 1957-2005. Contours denote the correlation among visibility variations in different regions.

With the changes in mean visibilities every five year from various regions in China (Fig. 9), and inferring from the spatial difference between the first five year since 2000's and the early of 1960's (Fig. 11b), the visibility in almost all regions in eastern China had $\sim 7$ to $15 \mathrm{~km}$ losses compared to those in the early of 1960's. The most significant visibility loss areas were found in Regions II and III (Fig. 11b), showing the more serious problems of regional haze in these regions. Region $\mathrm{V}$ and some small areas in northeast and northwest China also had the similar visibility loss rate (Fig. 11a). The total loss of visibility was about $10 \mathrm{~km}$ in eastern China since 1960's with a mean rate of decrease of about $0.2 \mathrm{~km} \mathrm{yr}^{-1}$. In western China, only half of the loss rate was found, probably due to less population density and relative lower economic growth (Fig. 11c). Because the visibility is highly attributable to the fine aerosol loading, today's haze is not a completely natural phenomenon.

Still referring to Fig. 11, the relatively higher population density areas in China (red series color regions in Fig. 11c) often correspond to large emissions of aerosol and its precursors, such as Region II, III, V and VI (Fig. 11d) where both relative higher $\mathrm{PM}_{10}$ levels (Table 2 ) and poor visibility were found (Figs. 9 and 11b). These four regions can be considered as the major regional haze areas in China (shadow areas marked in Fig. 11a) with high GDP growth and high aerosol emissions (Fig. 11d) from industrial activities, residential and commercial sectors. The high emissions super- imposed with the contributions of topography and meteorological features form the haze problems there. Although the total emissions in Region I are higher than those in Regions $\mathrm{V}$ and VI (Fig. 11d), the overall visibility loss is much smaller than in Regions V and VI, which is probably due to its larger area and favorable meteorological conditions for pollutants to diffuse. Consequently, this region is not regarded as one of the major haze areas in China even though some local poor visibility was found such as in Liaoning province with high emissions.

\section{Summary}

Two years (2006-2007) aerosol chemical compositions at 16 urban, rural and remote sites as well as the regional haze distributions are investigated for a better understanding of the characteristics of regional haze and atmospheric aerosols, their distributions, variations and chemical signatures in China.

The major findings of this study can be summarized as follows:

- Aerosol composition data show that $\mathrm{PM}_{10}$ in most of the CAWNET sites, expect at the two remote sites of Akdala and Zhuzhang, is characterized by high levels of mineral aerosol, which is partially a result of Asian desert dust transport, and partially contributions 

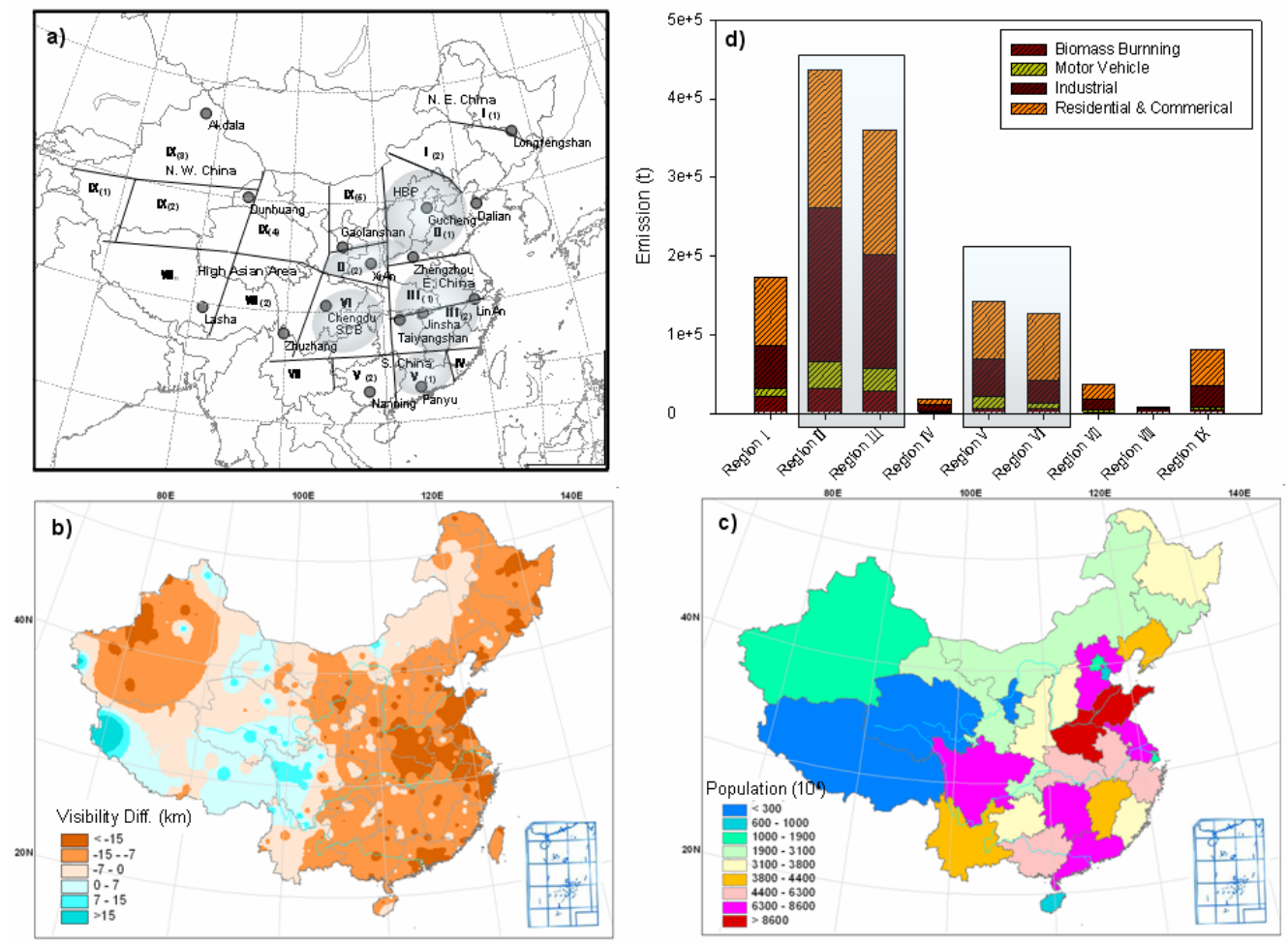

Fig. 11. (a) Nine similar visibility changing regions in China. The four major haze regions are marked with shadow; (b) Differences in five year mean visibilities between 2001-2005 and 1961-1965. Minus value with gradually darker colors represent the loss of visibility; (c) Population during 2001-2005 (NBSC, 2008); (d) Total emission of aerosol and its precious gas from nine regions of China. Original emission data from the reference (Cao et al., 2010).

from urban fugitive dust/fly ash sources. The annual mean concentrations of $\sim 75$ and $55 \mu \mathrm{g} \mathrm{m}^{-3}$ for mineral aerosol in urban and rural areas, respectively, are almost equivalent to the sum of all kind of aerosols in urban Europe, showing the substantial contributions of mineral aerosol to the high regional background of aerosol mass in China. This characteristic is also true for aerosol in other Asian areas, which is the most significant difference between Asian and European, US aerosol compositions. Due to the high level of mineral aerosol in Asia and especially in China, it is worth to pay a particular attention to the $\mathrm{CCN}$ activation capacity enhancement of mineral aerosol through heterogeneous chemical reaction with polluted gases in the region.

- In China, the total PM levels follow a clear seasonal pattern with a winter peak and summer low. A broader pattern is observed, especially at northwestern and northern China, with uplift in spring due to the higher frequency of Asian sand and dust episodes. No obvious seasonal variation was found for $\mathrm{SCB}$, the large basin in S. W. China, and Lhasa in High Asian Area, exhibiting relatively independent variations and fewer influences from other areas.
- Similar to bulk PM, the relatively higher concentration is found for mineral aerosol in spring that is a signal of Asian desert dust. A typical summer minimum and autumn to winter increasing pattern is also observed for urban mineral, showing the large influences of urban fugitive dust on the seasonal variation of this aerosol type.

- As the second largest aerosol component in most areas of China, sulfate was found to have relative higher concentrations with annual mean values of $\sim 34$ and $16 \mu \mathrm{g} \mathrm{m}^{-3}$ at urban and rural sites, respectively. The sulfate levels at urban sites increase progressively from June to July to exhibit an obvious uplift in mid-summer, due to plenty of $\mathrm{SO}_{4}^{2-}$ and gas-phase $\mathrm{NH}_{3}$ in urban area, enhanced photochemistry, low air mass ventilation on a regional scale. As a result, less ammonium nitrate can be formed due to insufficient $\mathrm{NH}_{3}$ left at urban area. No secondary peak for nitrate in summer is found as for sulfate and ammonium product, showing the strong ability of sulfate to associate with ammonium. The annual mean nitrate levels are $\sim 15$ and $7.9 \mu \mathrm{g} \mathrm{m}^{-3}$ for urban and rural aerosol, respectively. Because of the increase of winter coal-combustion emission in both urban and 
rural areas as the largest source for nitrate precursors in the country, it is not difficult to understand why nitrate peaks are observed in winter associated with low temperature.

- Because of much higher $\mathrm{NH}_{4}^{+}$mass concentration found in urban $\left(\sim 12 \mu \mathrm{g} \mathrm{m}^{-3}\right)$ than in rural areas $\left(5.6 \mu \mathrm{g} \mathrm{m}^{-3}\right)$, and the important role of $\mathrm{NH}_{3}$ in aerosol acidity, the aerosols in urban areas are nearly neutralized by having relative higher $\mathrm{NH}_{4}^{+}$, leaving the aerosols in the rural area somewhat acidic, where even some $\mathrm{Ca}^{2+}$ and $\mathrm{K}^{+}$ can participate in the neutralization processes.

- Almost with the same level of sulfate, OC aerosol finds the annual mean concentrations of $\sim 30$ and $18 \mu \mathrm{g} \mathrm{m}^{-3}$ at urban and rural sites, respectively. EC generally vary at two levels, $\sim 8.6 \mu \mathrm{g} \mathrm{m}^{-3}$ for urban hotspot, and $\sim 3.4 \mu \mathrm{g} \mathrm{m}^{-3}$ for regional background. The OC/EC ratio is close to 8.7 at remote sites and 5.5 at rural ones, which is explained by the biomass burning and the enhanced formation of SOC from both anthropogenic and biogenic precursors. The $\mathrm{OC} / \mathrm{EC}$ ratio is around 3.5 for urban aerosol, showing the strong influence of local emission source. The SOC can contribute an annually averaged $\sim 55 \%$ and $60 \%$ to the total urban and rural OC aerosols, respectively, and this source of OC was enhanced around May to June and October, especially in regional background aerosol with increasing contribution from biomass burning emission in China. Accurate determination and better parameterization of SOC in numerical models is still subject to a great uncertainty, and is an important factor to accurately estimate the impact of aerosol scattering effects in modeling community.

- As to the global aerosols, the mineral, sulfate and OC fractions are also found to be responsible for most of the aerosol masses (less than $\mathrm{PM}_{10}$ ) at the majority of areas thought the world, followed by nitrate, ammonium and EC. Globally, the mass concentrations of these major aerosols in North America and Europe are relatively lower than those in S. E. Asia, S. Asia and China.

- Based on the similar variation trend of observed visibility, China can be classified into nine typical regions, four of which have witnessed the largest loss of visibility in recent decades, associated with the increasing $\mathrm{PM}_{10}$ levels, and therefore are called major haze regions. These high PM in hazy regions are attributed to the proximity of emission sources, associated topography and meteorological features. Because the visibility is highly attributable to the fine aerosol loading, today's haze is not a completely natural phenomenon.
Acknowledgements. This research was supported by grants from National Key Project of Basic Research (2011CB403401), (2010CB955608) and Specific Team Fund of CAMS.

Edited by: J. Brandt

\section{References}

Bond, T. C., Streets, D. G., Yarber, K. F., Nelson, S. M., and Woo, J.: A technology-based global inventory of black and organic carbon emissions from combustion, J. Geophys. Res., 109, 1-43, 2004.

Bourotte, C., Curi-Amarante, A. P., Forti, M. C., Pereira, L. A. A., Braga, A. L., and Lotufo, P. A.: Association between ionic composition of fine and coarse aerosol soluble fraction and peak expiratory flow of asthmatic patients in Sao Paulo city (Brazil), Atmos. Environ., 41, 2036-2048, 2007.

Cao, G., Zhang, X., and Zheng, F.: Inventory of black carbon and organic carbon emissions from china, Atmos. Environ., 40, 6516-6527, 2006

Cao, G. L., An, X. Q., Zhou, C. H., Ren, Y. Q., and Tu, J.: Emission inventory of air pollutants in china, China Environmental Science, 30, 900-906, 2010.

Castro, L. M., Pio, C. A., Harrison, R. M., and Smith, D. J. T.: Carbonaceous aerosol in urban and rural european atmospheres: Estimation of secondary organic carbon concentrations, Atmos. Environ., 33, 2771-2781, 1999.

Chakraborty, A. and Gupta, T.: Chemical Characterization and Source Apportionment of Submicron (PM1) Aerosol in Kanpur Region, India, Aerosol Air Qual. Res., 10, 433-445, 2010.

Chang, D., Song, Y., and Liu, B.: Visibility trends in six megacities in China 1973-2007, Atmos. Res., 94, 161-167, 2009.

Chow, J. C., Watson, J. G., Pritchett, L. C., Pierson, W. R., Frazier, C. A., and Purcell, R. G.: The dri thermal/optical reflectance carbon analysis system: Description, evaluation and applications in u.S. Air quality studies, Atmos. Environ., 27A, 1185-1201, 1993.

Chow, J. C., Watson, J. G., Chen, L.-W. A., Arnott, W. P., Moosmüller, H., and Fung, K. K.: Equivalence of elemental carbon by thermal/optical reflectance and transmittance with different temperature protocols, Environ. Sci. Technol., 38, 4414 4422, 2004.

Decesari, S., Facchini, M. C., Mircea, M., Cavalli, F., and Fuzzi, S.: Solubility properties of surfactants in atmospheric aerosol and cloud/fog water samples, J. Geophys. Res, 108, 4685, doi:4610.1029/2003JD003566, 2003.

Decesari, S., Facchini, M. C., Carbone, C., Giulianelli, L., Rinaldi, M., Finessi, E., Fuzzi, S., Marinoni, A., Cristofanelli, P., Duchi, R., Bonasoni, P., Vuillermoz, E., Cozic, J., Jaffrezo, J. L., and Laj, P.: Chemical composition of PM10 and PM1 at the high-altitude Himalayan station Nepal Climate ObservatoryPyramid (NCO-P) (5079 m a.s.l.), Atmos. Chem. Phys. Discuss., 9, 25487-25522, doi:10.5194/acpd-9-25487-2009, 2009.

Delfino, R. J., Gong Jr, H., W. S. L., D.Pellizzari, E., and Hu, Y.: Asthma symptoms in hispanic children and daily ambient exposures to toxic and criteria air pollutants, Environ. Health Persp., 111, 649-656, 2003. 
Deng, X., Tie, X., Wu, D., Zhou, X. J., Bi, X. Y., Tan, H. B. and $\mathrm{Li}$, F.: Long-term trend of visibility and its characterizations in the Pearl River Delta (PRD) region, China, Atmos. Environ., 42, 1424-1435, 2008.

Dzubay, T. G., Morosoff, N., Whitaker, G. L., Yasuda, H., F., Bazan, R. L. Bennett, J., Cooper, W. J. Courtney, C. A., Frzier, R. C., Gatti, M., Germani, G., Gordon, S., Hanamura, R. B., Kellogg, J., Rhodes, R., and Schindler, J. S.: Polymer Film Standards for X-Ray Fluorescence Spectrometers, J. Trace Microprobe T., 5, 327-341, 1987.

Facchini, M. C., Mircea, M., Fuzzi, S., and Charlson, R. J.: Cloud albedo enhancement by surface-active organic solutes in growing droplets, Nature, 401, 257-259, 1999.

Feng, W. Y., Broadwin, R., Green, S., and Lipsett, M.: The effects of components of fine particulate air pollution on mortality in california-results from calfine. Bart ostro, Environ. Health Persp., 115, 13-19, 2007.

Forster, P., Ramaswamy, V., Artaxo, P., Berntsen, T., Betts, R., Fahey, D. W., Haywood, J., Lean, J., Lowe, D. C., Myhre, G., Nganga, J., Prinn, R., Raga, G., Schulz, M., and Dorland, R. V.: Changes in atmospheric constituents and in radiative forcing $[\mathrm{m}] / /$ ipcc. Climate change 2007: The physical science basis. Contribution of working group i to the fourth assessment report of the intergovernmental panel on climate change, edited by: Solomon, S., Qin, D., Manning, M., Chen, Z., Marquis, M., Averyt, K. B., Tignor, M., and Miller, H. L., Cambridge, United Kingdom and New York, USA, Cambridge University Press, 2007.

Fu, X. H., Xiao, G., Jiang, Y. Y., and Gao, L.: Characteristics of haze variation in recent 53 years andanalysis of meteorological factors in Yichang, Resources and Environment in the Yangtze Basin, CNKI:SUN:CJLY.0.2010-02-009, 2010.

Gong, S. L., Zhang, X. Y., Zhao, T. L., Zhang, X. B., Barrie, L. A., McKendry, I. G., and Zhao, C. S.: A simulated climatology of asian dust aerosol and its trans-pacific transport. Part ii: Interannual variability and climate connections, J. Climate, 19, 104-122, 2006.

Gullu, H. G., Ölmez, I., and Tuncel, G.: Temporal variability of atmospheric trace element concentrations over the eastern mediterranean sea, Spectrochimica Acta, B55, 1135, 2000.

Guo, J.: Climatic characteristics of atmospheric haze in Tianjin Area, Urban Environment \& Urban Ecology, CNKI:SUN:CHCS.0.2008-03-003, 2008.

Hagler, G. S. W., Bergin, M. H., Salmon, L. G., Yu, J. Z., Wan, E. C. H., Zheng, M., Zeng, L. M., Kiang, C. S., Zhang, Y. H., Lau, A. K. H., and Schauer, J.: Source areas and chemical composition of fine particulate matter in the pearl river delta region of china, Atmos. Environ., 40, 3802-3815, 2006.

Hallquist, M., Wenger, J. C., Baltensperger, U., Rudich, Y., Simpson, D., Claeys, M., Dommen, J., Donahue, N. M., George, C., Goldstein, A. H., Hamilton, J. F., Herrmann, H., Hoffmann, T., Iinuma, Y., Jang, M., Jenkin, M. E., Jimenez, J. L., Kiendler-Scharr, A., Maenhaut, W., McFiggans, G., Mentel, Th. F., Monod, A., Prévôt, A. S. H., Seinfeld, J. H., Surratt, J. D., Szmigielski, R., and Wildt, J.: The formation, properties and impact of secondary organic aerosol: current and emerging issues, Atmos. Chem. Phys., 9, 5155-5236, doi:10.5194/acp-95155-2009, 2009.

He, K., Yang, F., Ma, Y., Zhang, Q., Yao, X., Chan, C. K., Cadle,
S., Chan, T., and Mulawa, P.: The characteristics of $\mathrm{pm}_{2.5}$ in beijing, china, Atmos. Environ., 35, 4959-4970, 2001.

Hueglin, C., Gehrig, R., Baltensperger, U., Gysel, M., Monn, C., and Vonmont, H.: Chemical characterisation of $\mathrm{pm}_{2.5}, \mathrm{pm}_{10}$ and coarse particles at urban, near-city and rural sites in switzerland, Atmos. Environ., 39, 637-651, 2005.

Hu, M., He, L. Y., Zhang, Y. H., Wang, M., Pyo Kim, Y., and Moon, K. C.: Seasonal variation of ionic species in fine particles at qingdao, Atmos. Environ., 36, 5853-5859, 2002.

Ito, K., Xue, N., and Thurston, G.: Spatial variation of $\mathrm{pm}_{2.5}$ chemical species and source-apportioned mass concentrations in new york city, Atmos. Environ, 38, 5269-5282, 2004.

Kellog, R. and Winberry, W. J.: EPA Compendium Method 10-3.3: Determination of Metals in Ambient Particulate Matter Using Xray Fluorescence (XRF) Spectroscopy; U.S. EPA, Washington, DC, 1999.

Khare, P. and Baruah, B. P.: Elemental characterization and source identification of $\mathrm{pm}_{2.5}$ using multivariate analysis at the suburban site of north-east india, Atmos. Res., 98, 148-162, 2010.

Kim, B. M., Teffera, S., and Zeldin, M. D.: Characterization of $\mathrm{pm}_{2.5}$ and $\mathrm{pm}_{10}$ in the south coast air basin of southern california: Part 1-spatial variations, J. Air \& Waste Manage, Assoc. 50, 2034-2044, 2000.

Kim, H.-S., Huh, J.-B., Hopke, P. K., Holsen, T. M., and Yi, S.-M.: Characteristics of the major chemical constituents of $\mathrm{pm}_{2.5}$ and smog events in seoul, korea in 2003 and 2004, Atmos. Environ., 41, 6762-6770, 2007

Kocak, M., Mihalopoulos, N., and Kubilay, N.: Chemical composition of the fine and coarse fraction of aerosols in the northeastern mediterranean, Atmos. Environ., 41, 7351-7368, 2007.

Koehler, K. A., Kreidenweis, S. M., DeMott, P. J., Petters, M. D., Prenni, A. J., and Carrico, C. M.: Hygroscopicity and cloud droplet activation of mineral dust aerosol, Geophys. Res. Lett., 36, L08805, doi:08810.01029/02009GL037348, 2009.

Kumar, P., Sokolik, I. N., and Nenes, A.: Measurements of cloud condensation nuclei activity and droplet activation kinetics of wet processed regional dust samples and minerals, Atmos. Chem. Phys. Discuss., 11, 12561-12605, doi:10.5194/acpd-1112561-2011, 2011.

Kumar, R., Srivastava, S. S., and Kumari, K. M.: Characteristics of aerosols over suburban and urban site of semiarid region in india: Seasonal and spatial variations, Aerosol Air Qual. Res., 7, 531-549, 2007.

Lee, H. S. and Kang, B. W.: Chemical characteristics of principal $\mathrm{pm}_{2.5}$ species in chongju, south korea, Atmos. Environ., 35, 739-749, 2001.

Lenschow, P., Abraham, H. J., Kutzner, K., Lutz, M., Preu, J. D., and Reichenbacher, W.: Some ideas about the sources of $\mathrm{pm}_{10}$, Atmos. Environ., 35, 23-33, 2001.

Levin, Z., Ganor, E., and Gladstein, V.: The effects of dust particles coated with sulfate on rain formation in the eastern mediterranean, J. Appl. Meteorol., 35, 1511-1523, 1996.

Liao, Y. F., Wu, X. Y., Pan, Z. X., Zhao, F. H., Zhu, Y. D., Duan, L. J., Li, C., Li, Y., Cui, W., and Li, Q. L.: Climatic Characteristics of Haze in Hunan Province During 1961-2006, Advances in Climate Change Research, CNKI:SUN:QHBH.0.2007-05-004, 2007.

Liu, N. W., Ma, Y. J., Liu, X. M., Wang, R. N., and Wang, Y. F.: Haze change in Shenyang during 1980-2009, Journal of Arid 
Land Resources and Environment, CNKI:SUN:GHZH.0.201010-018, 2010.

Liu, W., Wang, Y., Russell, A., and Edgerton, E. S.: Atmospheric aerosol over two urban-rural pairs in the southeastern united states: Chemical composition and possible sources, Atmos. Environ., 39, 4453-4470, 2005.

Lodhi, A., Ghauri, B., Khan, M. R., Rahman, S., and Shafique, S.: Particulate matter $\left(\mathrm{pm}_{2.5}\right)$ concentration and source apportionment in lahore, J. Braz. Chem. Soc., 20, 1811-1820, 2009.

Lu, Z., Streets, D. G., Zhang, Q., Wang, S., Carmichael, G. R., Cheng, Y. F., Wei, C., Chin, M., Diehl, T., and Tan, Q.: Sulfur dioxide emissions in China and sulfur trends in East Asia since 2000, Atmos. Chem. Phys., 10, 6311-6331, doi:10.5194/acp-106311-2010, 2010.

Malm, W. C. and Schichtel, B. A.: Spatial and monthly trends in speciated fine particle concentration in the united states, J. Geophys. Res., 109, 1-22, doi:10.1029/2003JD003739, 2004.

Malm, W. C., Sisler, J. F., Huffman, D., Eldred, R. A., and Cahill, T. A.: Spatial and seasonal trends in particle concentration and optical extinction in the U.S., J. Geophys. Res., 99, 1347-1370, 1994.

Miyazaki, Y., Kondo, Y., Takegawa, N., Komazaki, Y., Kawamura, K., Mochida, M., Okuzawa, K., and Weber, R. J.: Time-resolved measurements of water-soluble organic carbon in tokyo, J. Geophys. Res., 111, D23206, doi:23210.21029/22006JD007125, 2006.

Myhre, G.: Consistency between satellite-derived and modeled estimates of the direct aerosol effect, Science, 325, 187-190, doi:10.1126/science.1174461, 2009.

NBSC: China statistical yearbook 2007, in Population, edited by: China, N. B. o. S. o., China Statistics Press, Beijing, China, 2008.

Nenes, A., Krom, M. D., Mihalopoulos, N., Van Cappellen, P., Shi, Z., Bougiatioti, A., Zarmpas, P., and Herut, B.: Atmospheric acidification of mineral aerosols: a source of bioavailable phosphorus for the oceans, Atmos. Chem. Phys., 11, 6265-6272, doi:10.5194/acp-11-6265-2011, 2011.

Oanha, N. T. K., Upadhyay, N., Zhuang, Y.-H., Hao, Z.-P., Murthy, D. V. S., Lestari, P., Villarin, J. T., Chengchua, K., Cof, H. X., Dung, N. T., and Lindgren, E. S.: Particulate air pollution in six asian cities: Spatial and temporal distributions, and associated sources, Atmos. Environ., 40, 3367-3380, 2006.

Ohara, T., Akimoto, H., Kurokawa, J., Horii, N., Yamaji, K., Yan, X., and Hayasaka, T.: An Asian emission inventory of anthropogenic emission sources for the period 1980-2020, Atmos. Chem. Phys., 7, 4419-4444, doi:10.5194/acp-7-4419-2007, 2007.

Pathak, R. K., Yao, X. H., and Chan, C. K.: Sampling artifacts of acidityand ionic species in $\mathrm{pm}_{2.5}$, Environmental Science and Technology, 38, 254-259, 2004.

Pérez, C., Nickovic, S., Pejanovic, G., Baldasano, J. M., and Özsoy, E.: Interactive dust-radiation modeling: A step to improve weather forecasts, J. Geophys. Res., 111, 1-17 2006.

Pérez, N., Pey, J., Querol, X., Alastuey, A., Lopez, J. M., and Viana, M.: Partitioning of major and trace components in $\mathrm{pm}_{10}-\mathrm{pm}_{2.5}-$ $\mathrm{pm}_{1}$ at an urban site in southern europe, Atmos. Environ., 42, 1677-1691, 2008.

Pöschl, U., Martin, S. T., Sinha, B., Chen, Q., Gunthe, S. S., Huffman, J. A., Borrmann, S., Farmer, D. K., Garland, R. M., Helas, G., Jimenez, J. L., King, S. M., Manzi, A., Mikhailov,
E., Pauliquevis, T., Petters, M. D., Prenni, A. J., Roldin, P., Rose, D., Schneider, J., Su, H., Zorn, S. R., Artaxo, P., and Andreae, M. O.: Rainforest aerosols as biogenic nuclei of clouds and precipitation in the amazon, Science, 329, 15131516, doi:1510.1126/science.1191056, 2010.

Puxbaum, H., Gomiscek, B., Kalina, M., Bauer, H., Salam, A., Stopper, S., Preining, O., and Hauck, H.: A dual site study of $\mathrm{pm}_{2.5}$ and $\mathrm{pm}_{10}$ aerosol chemistry in the larger region of vienna, austria, Atmos. Environ., 38, 3949-3958, 2004.

Qu, W. J., Zhang, X. Y., Arimoto, R., Wang, Y. Q., Wang, D., Sheng, L. F., and Fu, G.: Aerosol background at two remote cawnet sites in western china, Sci. Total Environ., 407, 35183529, doi:3510.1016/j.scitotenv.2009.3502.3012, 2009.

Querol, X., Alastuey, A., Rodríguez, S., Plana, F., Ruiz, C. R., Cots, N., Massague, G., and Puig, O.: Pm10 and $\mathrm{pm}_{2.5}$ source apportionment in the barcelona metropolitan area, catalonia, spain, Atmos. Environ., 35/36, 6407-6419, 2001.

Querol, X., Alastuey, A., Ruiz, C. R., Artinano, B., Hansson, H. C., Harrison, R. M., Buringh, E., ten Brink, H. M., Lutz, M., Bruckmann, P., Straehl, P., and Schneider, J.: Speciation and origin of $\mathrm{pm}_{10}$ and $\mathrm{pm}_{2.5}$ in selected european cities, Atmos. Environ., 38, 6547-6555, 2004

Querol, X., Alastuey, A., Moreno, T., Viana, M. M., Castillo, S. Pey, J., Rodrıguez, S., Artinano, B., Salvador, P., Sanchez, M., Garcia Dos Santos, S., Herce Garraleta, M. D., Fernandez-Patier, R., Moreno-Grau, S., Minguillon, M. C., Monfort, E., Sanz, M. J., Palomo-Marın, R., Pinilla-Gil, E., and Cuevas, E.: Spatial and temporal variations in airborne particulate matter $\left(\mathrm{pm}_{10}\right.$ and $\mathrm{pm}_{2.5}$ ) across spain 1999-2005, Atmos. Environ., 42, 3964 3979, doi:10.1016/j.atmosenv. 2006.10.071., 2008.

Querol, X., Alastuey, A., Pey, J., Cusack, M., Pérez, N., Mihalopoulos, N., Theodosi, C., Gerasopoulos, E., Kubilay, N., and Koak, M.: Variability in regional background aerosols within the Mediterranean, Atmos. Chem. Phys. Discuss., 9, 10153-10192, doi:10.5194/acpd-9-10153-2009, 2009.

Rastogi, N. and Sarin, M. M.: Long-term characterization of ionic species in aerosols from urban and high-altitude sites in western india: Role of mineral dust and anthropogenic sources, Atmos. Environ., 39, 5541-5554, 2005

Ram, K., Sarin, M. M., and Hegde, P.: Long-term record of aerosol optical properties and chemical composition from a high-altitude site (Manora Peak) in Central Himalaya, Atmos. Chem. Phys., 10, 11791-11803, doi:10.5194/acp-10-11791-2010, 2010.

Raman, R. S., Ramachandran, S., and Rastogi, N.: Source identification of ambient aerosols over an urban region in western india, J. Environ. Monitor., 12, 1330-1340, 2010.

Rodriguez, S., Querol, X., Alastuey, A., and Plana, F.: Sources and processes affecting levels and composition 5 of atmospheric aerosol in the western mediterranean, J. Geophys. Res., 107, 4777, doi:4710.1029/2001JD001488., 2002.

Rodriguez, S., Querol, X., Alastuey, A., Viana, M. M., Alarcon, M., E, M., and Ruiz, C. R.: Comparative $\mathrm{pm}_{10}-\mathrm{pm}_{2.5}$ source contribution study at rural, urban and industrial sites during $\mathrm{pm}$ episodes in eastern spain, Sci. Total Environ., 328, 95-113, 2004.

Roosli, M., Theis, G., nzli, N. K., Staehelin, J., Mathys, P., Oglesby, L., Camenzind, M., and Braun-FahrlaKnder, C.: Temporal and spatial variation of the chemical composition of $\mathrm{pm}_{10}$ at urban and rural sites in the basel area, switzerland, Atmos. Environ., $35,3701-3713,2001$. 
Safai, P. D., Budhavant, K. B., Rao, P. S. P., Ali, K., and Sinha, A.: Source characterization for aerosol constituents and changing roles of calcium and ammonium aerosols in the neutralization of aerosol acidity at a semi-urban site in sw india, Atmos. Res., 98, 78-88, 2010.

Sawant, A. A., Na, K., Zhu, X., and Cocker III, D. R.: Chemical characterization of outdoor $\mathrm{pm}_{2.5}$ and gas-phase compounds in mira loma, california, Atmos. Environ., 38, 5517-5528, 2004.

Shresth, A. B., Wake, C. P., Dibb, J. E., Mayewski, P. A., Whitlow, S. I., Carmichael, G. R., and Ferm, M.: Seasonal variations in aerosol concentrations and compositions in the nepal himalaya, Atmos. Environ., 34, 3349-3363, 2000.

Stone, E., Schauer, J., Quraishi, T. A., and Mahmood, A.: Chemical characterization and source apportionment of fine and coarse particulate matter in lahore, pakistan, Atmos. Environ., 44, 10621070, 2010.

Streets, D. G., Bond, T. C., Carmichael, G. R., Fernandes, S. D., Fu, Q., He, D., Klimont, Z., Nelson, S. M., Tsai, N. Y., Wang, M. Q., Woo, J.-H., and Yarber, K. F.: An inventory of gaseous and primary aerosol emissions in asia in the year 2000, J. Geophys. Res., 108, 8809, doi:8810.1029/2002JD003093, 2003.

Sullivan, A., Peltier, R. E., Brock, C. A., Gouw, J. A. d., Holloway, J. S., Warneke, C., Wollny, A. G., and Weber, R. J.: Airborne measurements of carbonaceous aerosol soluble in water over northeastern united states: Method development and an investigation into water-soluble organic carbon sources, J. Geophys. Res, 111, D23S46, doi:10.1029/2006JD007072, 2006.

Tanner, R. L., Parkhurst, W. J., Valente, M. L., and Phillips, W. D.: Regional composition of $\mathrm{pm}_{2.5}$ aerosols measured at urban, rural and "Background" Sites in the tennessee valley, Atmos. Environ., 38, 3143-3153, 2004.

Theodosi, C., Im, U., Bougiatioti, A., Zarmpas, P., Yenigun, O., and Mihalopoulos, N.: Aerosol chemical composition over istanbul, Sci. Total Environ., 408, 2482-2491, 2010.

Tsigaridis, K. and Kanakidou, M.: Global modelling of secondary organic aerosol in the troposphere: a sensitivity analysis, Atmos. Chem. Phys., 3, 1849-1869, doi:10.5194/acp-3-1849-2003, 2003.

Tsigaridis, K. and Kanakidou, M.: Secondary organic aerosol importance in the future atmosphere, Atmos. Environ., 41, 46824692, 2007.

Viana, M., Chi, X., Maenhaut, W., Querol, X., Alastuey, A., Mikuska, P., and Vecera, Z.: Organic and elemental carbon concentrations during summer and winter sampling campaigns in barcelona, spain, Atmos. Environ., 40, 2180-2193, 2006.

Viana, M., Maenhaut, W., Chi, X., Querol, X., and Alastuey, A.: Comparative chemical mass closure of fine and coarse aerosols at two sites in south and west europe: Implications for eu air pollution policies, Atmos. Environ., 41, 315-326, 2007.

Viana, M., Querol, X., Ballester, F., Llop, S., Esplugues, A., Fernandez Patier, R., Garcia Dos Santos, S., and Herce, M. D.: Characterising exposure to $\mathrm{pm}$ aerosols for an epidemiological study, Atmos. Environ., 42, 1552-1568, 2008.

Wang, H. and Shooter, D.: Water soluble ions of atmospheric aerosols in three NewZealand cities: seasonal changes and sources, Atmos. Environ., 35, 6031-6040, 2007.

Wang, G., Wang, H., Yu, Y., Gao, S., Feng, J., Gao, S., and Wang, L.: Chemical characterization of water-soluble components of $\mathrm{pm}_{10}$ and $\mathrm{pm}_{2.5}$ atmospheric aerosols in five locations of nan- jing, china, Atmos. Environ., 37, 2893-2902, 2003.

Wang, H., Zhang, X. Y., Gong, S. L., Chen, Y., Shi, G. Y., and Li, W.: Radiative feedback of dust aerosols on the eastasian dust storms, J. Geophys. Res., 115, D23214, doi:23210.21029/22009JD013430, 2010.

Wang, Y., Zhuang, G., Tang, A., Yuan, H., Sun, Y., Chen, S., and Zheng, A.: The ion chemistry and the source of $\mathrm{pm}_{2.5}$ aerosol in beijing, Atmos. Environ., 39, 3771-3784, 2005.

Wang, Y., Zhuang, G., Zhang, X., Huang, K., Xu, C., Tang, A., Chen, J., and An, Z.: The ion chemistry, seasonal cycle, and sources of $\mathrm{pm}_{2.5}$ and tsp aerosol in shanghai, Atmos. Environ., 40, 2935-2952, 2006.

Wu, D., Deng, X. J., Bi, X. Y., Li, F., Tan, H. B., and Liao, G. L.: Study on the visibility reduction caused by atmospheric haze in Guangzhou area, J. Trop. Meteorol., 13, 77-80, 2007.

Weber, R. J., Sullivan, A. P., Peltier, R. E., Russell, A., Yan, B., Zheng, M., Gouw, J. A. d., Warneke, C., Brock, C., Holloway, J. S., Atlas, E. L., and Edgerton, E.: A study of secondary organic aerosol formation in the anthropogenicinfluenced southeastern united states, J. Geophys. Res., 112, D13302, doi:10.1029/12007JD008408, 2007.

Yang, M., Howell, S. G., Zhuang, J., and Huebert, B. J.: Attribution of aerosol light absorption to black carbon, brown carbon, and dust in china - interpretations of atmospheric measurements during east-aire, Atmos. Chem. Phys., 9, 2035-2050 doi:2010.5194/acp-2039-2035-2009, 2009.

Yang, W. F., Yin, Y., Wei, Y. X., and Chen, K.: Characteristics and sources of metal elements in PM_(2.5) during hazy days in Nanjing, China Environmental Science, CNKI:SUN:ZGHJ.0.201001-003, 2010.

Yao, X., Chan, C. K., Fang, M., Cadle, S., Chan, T., Mulawa, P., He, K., and Ye, B.: The water-soluble ionic composition of $\mathrm{pm}_{2.5}$ in shanghai and beijing, china, Atmos. Environ., 36, 4223-4234, 2002.

Ye, B., Ji, X., Yang, H., Yao, X., Chan, C. K., Cadle, S. H., Chan, T., and Mulawa, P. A.: Concentration and chemical composition of $\mathrm{pm}_{2.5}$ in shanghai for a 1-year period, Atmos. Environ., 37, 499-510, 2003.

Yin, J. and Harrison, R. M.: Pragmatic mass closure study for $\mathrm{pm}_{1.0}, \mathrm{pm}_{2.5}$ and $\mathrm{pm}_{10}$ at roadside, urban background and rural sites, Atmos. Environ., 42, 980-988, 2008.

Yttri, K. E.: Concentrations of particulate matter $\left(\mathrm{pm}_{10}, \mathrm{pm}_{2.5}\right)$ in norway. Annual and seasonal trends and spatial variabilityAnnex A, EMEP Particulate Matter Assessment Report, Part B, report EMEP/CCC-Report 8/2007, 292-307, ref. O-7726, 2007.

Zhang, Q., Canagaratna, M. R., Jayne, J. T., Worsnop, D. R., and Jimenez, J.-L.: Time- and size-resolved chemical composition of submicron particles in pittsburgh: Implications for aerosol sources and processes, J. Geophys. Res., 110, D07S09, doi:10.1029/2004JD004649, 2005a.

Zhang, Q., Streets, D. G., Carmichael, G. R., He, K., Huo, H., Kannari, A., Klimont, Z., Park, I., Reddy, S., Fu, J. S., Chen, D., Duan, L., Lei, Y., Wang, L., and Yao, Z.: Asian emissions in 2006 for the NASA INTEX-B mission, Atmos. Chem. Phys. Discuss., 9, 4081-4139, doi:10.5194/acpd-9-4081-2009, 2009a.

Zhang, X., Arimoto, R., An, Z., Chen, T., Zhu, G., and Wang, X.: Atmospheric trace elements over source regions for chinese dust: Concentrations, sources and atmospheric deposition on the loess plateau, Atmos. Environ., 27, 2051-2067, 1993. 
Zhang, X. Y., Zhang, G. Y., Zhu, G. H., Zhang, D. E., An, Z. S., Chen, T., and Huang, X. P.: Elemental tracers for chinese source dust, Sci. China Ser. D, 512-521, 1996.

Zhang, X. Y., Arimoto, R., and An, Z. S: Dust emission from Chinese desert sources linked to variations in atmospheric circulation, J. Geophys. Res. 102, 28041-28047, 1997.

Zhang, X. Y., Cao, J. J., Li, L. M., Arimoto, R., Cheng, Y., Huebert, B., and Wang, D.: Characterization of atmospheric aerosol over xian in the south margin of the loess plateau, china, Atmos. Environ., 36, 4189-4199, 2002.

Zhang, X. Y., Gong, S. L., Zhao, T. L., Arimoto, R., Wang, Y. Q., and Zhou, Z. J.: Sources of asian dust and role of climate change versus desertification in asian dust emission, Geophys. Res. Lett., 30, 012272, doi:10.1029/2003GL018206, 2003a.

Zhang, X. Y., Gong, S. L., Arimoto, R., Shen, Z. X., Mei, F. M., Wang, D., and Cheng, Y.: Characterization and temporal variation of Asian dust aerosol from a site in the northern Chinese deserts, J. Atmosp. Chem., 44, 241-257, 2003b.
Zhang, X. Y., Wang, Y. Q., Wang, D., and Gong, S. L.: Characterization and sources of regional-scale transported carbonaceous and dust aerosols from different pathways in costal and sandy land areas of china, J. Geophys. Res., 110, D15301, doi:15310.11029/12004JD005457, 2005b.

Zhang, X. Y., Wang, Y. Q., Zhang, X. C., Guo, W., and Gong, S. L.: Carbonaceous aerosol composition over various regions of china during 2006, J. Geophys. Res, 113, D14111, doi:10.1029/2007JD009525, 2008a.

Zhang, X. Y., Wang, Y. Q., Zhang, X. C., Niu, T., Gong, S. L., Zhao, P., Jin, J. L., and Yu, M.: Aerosol monitoring at multiple locations in china: Contributions of ec and dust to aerosol light absorption, Tellus B, 60, 647-656, doi:610.1111/j.16000889.2008.00359, 2008b.

Zhang, X., Wang, Y. Q., Lin, W. L., Zhang, Y. M., Zhang, X. C., Gong, S., Zhao, P., Yang, Y. Q., Wang, J. Z., Hou, Q., Zhang, X. L., Che, H. Z., Guo, J. P., and Li, Y.: Changes of atmospheric compositions and optical property over beijing: 2008 olympic monitoring campaign, B. Am. Soc., 90, 1633-1651, 2009 b. 